The finance-growth nexus in the age of financialisation: An empirical reassessment for the European Union countries

Ricardo Barradas

Novembro 2018

WP n. ${ }^{\circ} 2018 / 07$

DOCUMENTO DE TRABALHO

WORKING PAPER

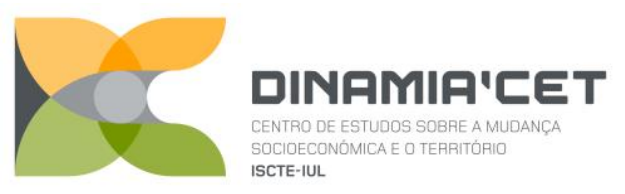

ISCTE IUL

Instituto Universitário de Lisboa

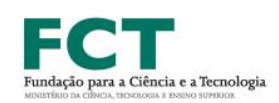




\section{The finance-growth nexus in the age of financialisation: An empirical reassessment for the European Union countries}

Ricardo Barradas*

WP n. ${ }^{\circ} 2018 / 07$

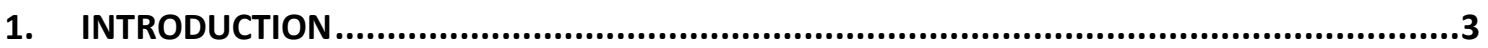

2. LITERATURE REVIEW ON THE FINANCE-GROWTH NEXUS: THEORETICAL AND EMPIRICAL EVIDENCE

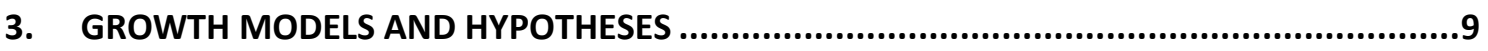

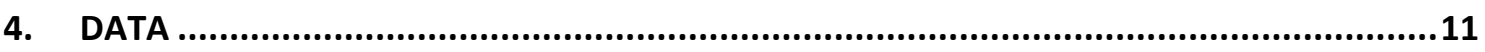

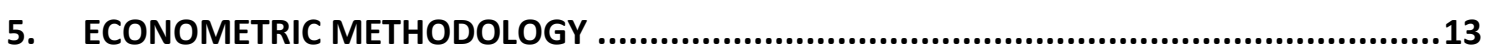

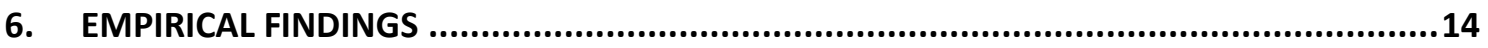

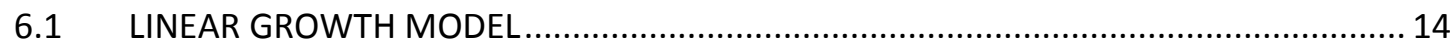

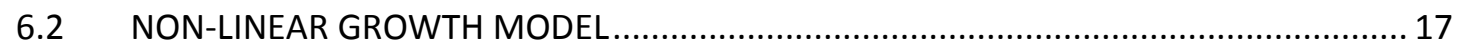

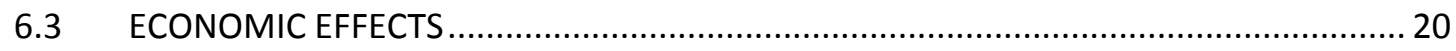

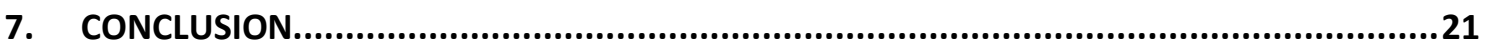

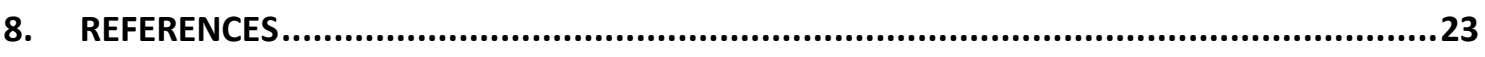

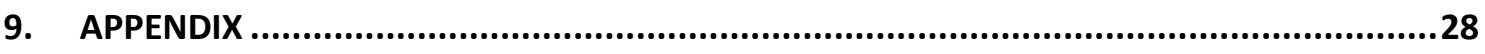

* Instituto Universitário de Lisboa (ISCTE-IUL), DINÂMIA'CET-IUL, Lisboa, Portugal. ESCS - Escola Superior de Comunicação Social, Instituto Politécnico de Lisboa, Lisboa, Portugal. ISCAL - Instituto Superior de Contabilidade e Administração de Lisboa, Instituto Politécnico de Lisboa, Lisboa, Portugal. E-mail: ricardo_barradas@iscte-iul.pt 


\title{
THE FINANCE-GROWTH NEXUS IN THE AGE OF FINANCIALISATION: AN EMPIRICAL REASSESSMENT FOR THE EUROPEAN UNION COUNTRIES ${ }^{1}$
}

\begin{abstract}
This paper draws an empirical reassessment of the finance-growth nexus by performing a panel data econometric analysis for all 28 European Union countries over 27 years from 1990 to 2016. Since the mid-1980s, the financial system has experienced a strong liberalisation and deregulation by preventing its beneficial effects on the real economy. This phenomenon, typically called financialisation, points to a negative view of finance and contradicts the wellentrenched hypothesis on the finance-growth nexus. We estimate both linear and non-linear growth models by incorporating seven proxies of finance (money supply, domestic credit, financial value added, short-term interest rate, long-term interest rate, stock market volume traded and stock market capitalisation) and five control variables (the lagged growth rate of the real per capita gross domestic product, the inflation rate, the general government consumption, the degree of trade openness and the education level of the population). Our results show that finance has impaired economic growth in the EU countries, both in the pre-crisis period and in the crisis and post-crisis periods. The enormous growth of domestic credit and of the financial value added have been restraining the economic growth of the EU countries since 1990 and particularly up until the Great Recession. This implies the need to reduce the prominence of finance, i.e. so-called de-financialisation, in the coming years in order to avoid the potential new 'secular stagnation' in the current age of financialisation.
\end{abstract}

\section{KEYWORDS}

Finance, Economic Growth, European Union, Panel Data, Least-Squares Dummy Variable Bias-Corrected Estimator

\section{JEL CLASSIFICATION}

C33, E44, 016 and $\mathrm{O} 47$

\footnotetext{
1 The usual disclaimer applies.

DINÂMIA'CET - IUL, Centro de Estudos sobre a Mudança Socioeconómica e o Território do Instituto Universitário de Lisboa (ISCTE-IUL)

Sala 2W4 - D | ISCTE-IUL - Av. das Forças Armadas 1649-026 Lisboa, PORTUGAL 


\section{INTRODUCTION}

During recent years and particularly until the Great Recession, the financial system suffered a process of strong liberalisation and deregulation as a means to restrain financial repression, to support financial development and to achieve a higher level of economic growth (Ricardo Barradas, 2016). As a consequence, the realm of finance has gained a huge preponderance since the mid-1980s giving rise to an excessive financial deepening with deleterious effects on the real economy (Peter L. Rousseau and Paul Wachtel, 2011; Adolfo Barajas, Ralph Chami and Seyed R. Yousefi, 2013; Era Dabla-Norris and Narapong Srivisal, 2013). This phenomenon, typically called financialisation, points to a negative view of finance, which seems to contradict the well-entrenched hypothesis on the finance-growth nexus (James B. Ang, 2008; Petra Valickova, Tomas Havranek and Roman Horvath, 2014; Phillip Arestis, Georgios Chortareas and Georgios Magkonis, 2015).

Accordingly, some empirical studies, for a large variety of countries and/or time periods, have emerged in recent years to assess the validity of the finance-growth nexus hypothesis in the age of financialisation. Most of these empirical studies find a weakening in the positive association between finance and economic growth or even a negative association between them (Felix Rioja and Neven Valev, 2004a and 2004b; Philippe Aghion, Peter Howitt and David Mayer-Foulkes, 2005; Ayhan Kose et al., 2006; Eswar S. Prasad, Raghuram G. Rajan and Arvind Subramanian, 2007; Rousseau and Wachtel, 2011; Stephen G. Cecchetti and Enisse Kharroubi, 2012; Barajas, Chami and Yousefi, 2013; Dabla-Norris and Srivisal, 2013; Thorsten Beck, Hans Degryse and Christiane Kneer, 2014; Max Breitenlechner, Martin Gächter and Friedrich Sindermann, 2015; Kizito U. Ehigiamusoe and Hooi H. Lean, 2017; Constantinos Alexiou, Sofoklis Vogiazas and Joseph G. Nellis, 2018).

This paper examines the impact of finance on economic growth in the European Union (EU) countries between 1990 and 2016 through a panel data econometric analysis, which extends the existing literature in at least seven different directions. Firstly, this paper is centred on EU countries, for which the empirical evidence is relatively scarce and exhibits mixed results (Alexiou, Vogiazas and Nellis, 2018). EU countries represent an interesting case study, namely because they have witnessed a strong growth of the financial system in recent years (Figures A6 to A12 in the Appendix) that have not led to a comparable a path of economic growth (Figure A1 in the Appendix). Secondly, the paper conducts a panel data econometric analysis, in a context where the empirical literature has been dominated by cross-country works probably due to the lack of available time series data (Ang, 2008). Panel data econometric analysis tends to be more advantageous than pure time series and/or pure cross-country analyses by offering the opportunity to work simultaneously with several countries over several years. This improves the 
accuracy and the reliability of the produced results due to the possibility of working with larger samples (Badi H. Baltagi, 2005; Chris Brooks, 2009). Thirdly, this paper assesses the impact of finance on economic growth both in the pre-crisis period and in the crisis and post-crisis periods, respectively. This is important taking into account the general recognition that the relationship between finance and economic growth is extremely complex and not stable over time (Anna Grochowska et al., 2014). Nonetheless, the majority of empirical studies on the finance-growth nexus only focus on the period until the Great Recession. Breitenlechner, Gächter and Sindermann (2015), Dilek Durusu-Ciftci, M. Serdar Ispir and Hakan Yetkiner (2017), Ehigiamusoe and Lean (2017) and Alexiou, Vogiazas and Nellis (2018) are the only exceptions, but they do not analyse this issue for the EU countries. Fourthly, the paper examines the relationship between finance and economic growth by estimating both linear and non-linear growth models, in a context where the latter have been quite neglected in the empirical literature. Cecchetti and Kharroubi (2012), Barajas, Chami and Yousefi (2013), Dabla-Norris and Srivisal (2013) and Beck, Degryse and Kneer (2014) are some exceptions and confirm that finance exerts an inverted U-shaped impact on economic growth. Fifthly, this paper uses an estimator that takes into account the potential endogeneity between finance and economic growth. This is quite relevant given the potential bi-directionality between finance and economic growth (Ang, 2008; Alexiou, Vogiazas and Nellis, 2018). Sixthly, the paper uses different proxies for finance, which allows to offer a complete picture on the role of finance on economic growth and to capture different dimensions of finance (Beck, Degryse and Kneer, 2014; Breitenlechner, Gächter and Sindermann, 2015). Seventhly, our growth models incorporate other important control variables in order to prevent the problem of omitted relevant variables that would imply the production of inconsistent and biased estimates (Jeffrey M. Wooldridge, 2003; Michael Kutner et al., 2005; Brooks, 2009).

Against this backdrop, our growth models are estimated using seven different proxies to capture the role of finance (money supply, domestic credit, financial value added, short-term interest rate, long-term interest rate, stock market volume traded and stock market capitalisation) and five control variables (the lagged growth rate of the real per capita gross domestic product, the inflation rate, the general government consumption, the degree of trade openness and the education level of the population). We use the least-squares dummy variables bias-corrected (LSDVBC) estimator to produce our results due to the existence of a dynamic panel data model, an unbalanced panel, a macro panel and a potential reverse causation between finance and economic growth.

The paper concludes that finance has been prejudicial for economic growth in the EU countries, both in the pre-crisis period and in the crisis and post-crisis periods. The huge growth 
of the domestic credit and of the financial value added has constrained a higher level of economic growth in the EU countries since 1990 and particularly until the Great Recession.

The rest of the paper is organised as follows. In Section 2, the literature review on the finance-growth nexus is presented, namely by describing the theoretical and empirical evidence around that. Section 3 describes the growth models that will be estimated, as well as the expected impacts of each variable included in these models. Data and econometric methodology are explained in Sections 4 and 5, respectively. Section 6 presents the empirical findings and a discussion of results. In Section 7, the main conclusions are addressed.

\section{LITERATURE REVIEW ON THE FINANCE-GROWTH NEXUS: THEORETICAL AND EMPIRICAL EVIDENCE}

It is widely acknowledged that the realm of finance has suffered a strong transformation in the last decades all over the world. Barradas (2016) makes a good description of this transformation by identifying three different stages in the evolution of the financial system, which reflect the different impacts of finance on the real economy.

The first stage - financial repression - was characterised by high levels of regulation and restrictions on the functioning of the financial system. During this period, administrative control was exercised by the central bank and/or by the government on the level of interest rates that can be paid on deposits or charged on loans, on the products and/or services that can be supplied by banks, and on the volume, direction and allocation of credit; along with legal requirements for high reserves and a strong control of international capital flows (Ang, 2008). In some countries, the majority of financial institutions were Stated-owned banks or Statedirected banks in order to support a wide range of economic and social purposes and to channel credit to specific sectors (Gerald A. Epstein, 2005). This financial repression restrained the quantity and the quality of investments, representing by itself a strong constraint on economic growth (Ronald I. McKinnon, 1973; Edward S. Shaw, 1973).

Against this backdrop, the financial system was subject to strong liberalisation and deregulation in the 1970s and 1980s giving rise to the second stage - financial development. Two different aspects were determinants to support this new liberalising and deregulatory paradigm. On the one hand, this was fostered by theoretical arguments on the potential advantages provided by the financial system. The majority of these advantages are related to the beneficial effects of the financial system on the reallocation of savings to finance entrepreneurs' investments, which spurs economic growth (Malcolm Sawyer, 2014). This is the 
'intermediation or financial facilitator view' in the words of Beck, Degryse and Kneer (2014), according to which the financial system facilitates the proper functioning of modern market economies by serving the development of the non-financial sectors. Ross Levine (2005), Ang (2008) and Arestis, Chortareas and Magkonis (2015) synthesise this belief by maintaining that the financial system is crucial to support a higher level of economic growth, because it produces information ex ante about investments, allocates capital, screens and monitors investments, exerts a certain control after the provision of funding, facilitates the trading of both financial and non-financial assets, diversifies risk, offers risk management services, promotes the exchange of goods and services, reduces the informational asymmetries and minimises transaction costs. Moreover, McKinnon (1973) and Shaw (1973) underline that liberalisation and deregulation are crucial to ensure that emerging and developing economies can access international capital markets, a necessary condition to boost their levels of economic growth. On the other hand, this was also supported by the emergence of several empirical studies that find a positive relationship between finance and economic growth. Ang (2008), Valickova, Havranek and Horvath (2014), Arestis, Chortareas and Magkonis (2015) provide a survey on the empirical literature on this matter, claiming that the finance-growth nexus is a well-recognised empirical fact for a huge variety of countries and/or time periods.

Financial liberalisation and deregulation implied the adoption of internal and external measures at a country-level, namely the elimination of interest rates ceilings, the reduction of legal reserve requirements, the abolition of State-directed credit programmes, the creation of more financial institutions and the privatisation of existing ones, the provision of a greater variety of financial products and/or services and the loosening of control on international capital flows (Ang, 2008; Sawyer, 2014 and 2015; Ehigiamusoe and Lean, 2017). As a consequence, the financial system acquired a great prominence since the mid-1980s by giving rise to an excessive financial deepening with negative repercussions on the economic and social spheres. The higher incidence of financial crises, the emergence of inflation episodes, the higher fragility of banking systems and the greater volatility of aggregate demand are some manifestations of the unsustainable nature of this new liberalising and deregulatory environment (Rousseau and Wachtel, 2011; Barajas, Chami and Yousefi, 2013; Dabla-Norris and Srivisal, 2013). This paved the way to the third stage - financialisation - transferring the deleterious effects of financial deepening onto the real economy.

From an empirical point of view, this negative view of finance is also corroborated by the emergence of several empirical studies finding a weakening in the positive relationship between finance and economic growth or even a negative relationship between them (Rioja and Valev, 2004a and 2004b; Aghion, Howitt and Mayer-Foulkes, 2005; Kose et al., 2006; Prasad, 
Rajan and Subramanian, 2007; Rousseau and Wachtel, 2011; Cecchetti and Kharroubi, 2012; Barajas, Chami and Yousefi, 2013; Dabla-Norris and Srivisal, 2013; Beck, Degryse and Kneer, 2014; Breitenlechner, Gächter and Sindermann, 2015; Ehigiamusoe and Lean, 2017; Alexiou, Vogiazas and Nellis, 2018). Lukas Menkhoff and Norbert Tolksdorf (2001) stress that there has been a 'disruptive relationship' between finance and economic growth in the last ten or twenty years, because the financial sphere started to follow its own logic and the real economy began to adapt to the consequences of this. These authors call this the 'decoupling hypothesis' between the financial system and the real economy. In the same vein, Cecchetti and Kharroubi (2012), Barajas, Chami and Yousefi (2013), Dabla-Norris and Srivisal (2013) and Beck, Degryse and Kneer (2014) conclude that there has been a non-linear relationship between finance and economic growth as a concave quadratic function, in a context where finance has an inverted Ushaped effect on economic growth. This means that from a certain threshold a further enlargement of the financial system can even reduce economic growth.

Several reasons are identified in the literature to explain this weakening or the reversal in the relationship between finance and economic growth in the age of financialisation. Firstly, the growth of the financial system has occurred essentially at the level of non-intermediation financial activities (proprietary trading, market making, provision of advisory services, insurance and other non-interest income generating activities), which have a less noticeable effect on economic growth (Beck, Degryse and Kneer, 2014). Sawyer (2014 and 2015) emphasises that the expansion of the financial system has been visible in the proliferation of derivatives, securitisation, shadow banking and the scale of financial asset transactions and not in activities directly connected with the linkage between savings and investment. This is also visible in the appearance of other financial institutions that do not directly favour financial intermediation, like investment funds, money market funds, hedge funds, private equity funds, special purpose vehicles, among others (Engelbert Stockhammer, 2010; Bill Lucarelli, 2012). Secondly, the relationship between savings and investments has also narrowed due to the liquidity function of the financial system, according to which savers are increasing the transactions of financial assets by rearranging their portfolios that do not generate a substantial amount of further funds for investors (Sawyer, 2014). Thirdly, the financial system has amplified the volatility of the aggregate demand and particularly the volatility of both consumption and investment (Dabla-Norris and Srivisal, 2013). Effectively, the unstable and speculative nature of stock markets does not favour the stability of economies (Ang, 2008). This is linked with the 'financial instability hypothesis' of Hyman P. Minsky (1991) and represents in itself a critique to Milton Friedman's (1953) argument that financial speculation is stabilising because it drives prices back to their fundamental levels (Thomas I. Palley, 2007). Fourthly, the

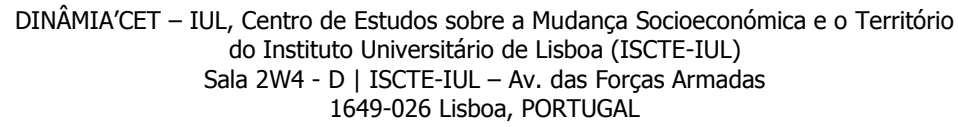


strong growth of credit in the age of financialisation has increased the vulnerability of banks and the likelihood of a systemic banking crisis (Rousseau and Wachtel, 2011). As claimed by these authors, this is particularly relevant due to the absence of legal and regulatory infrastructures to deal with this. The strong growth in credit has increased debt levels, which makes economies more vulnerable to any negative shocks (Stockhammer, 2010; Natascha van der Zwan, 2014). Additionally, the majority of credit has been channelled to households for mortgage purposes (Costas Lapavitsas, 2011), which prevents higher rates of physical capital accumulation that are crucial to sustain more investment, economic growth and employment creation (Özgür Orhangazi, 2008a). Fifthly, banks tend to encourage risk-aversion behaviour on the part of investors in order to ensure that they pay their debts. Investors respond to these pressures by investing excessively in tangible assets that can be used as collateral instead of in knowledgebased assets, which constrains the corporations' opportunity to expand the potential growth of economies (Ang, 2008). Sixthly, the financial system competes with the remaining sectors for scarce resources, which suggests that financial booms are not growth-enhancing (Cecchetti and Kharroubi, 2012). The financial system also absorbs resources that are often highly paid, which decreases the available resources to real and productive sectors (Sawyer, 2014). Seventhly, imperfect competition, rent extraction, implicit insurance due to bailouts and negative externalities from auxiliary services which benefit some clients and not society as a whole are other problems arising from an oversized financial system (Beck, Degryse and Kneer, 2014). Eighthly, the financial system only boosts economic growth by encouraging innovative investments in the early stages of economic development in line with the 'supply leading hypothesis' (Alexiou, Vogiazas and Nellis, 2018). Effectively, these authors state that economic growth itself increases the demand for more financial services boosting the financial system, which makes the 'demand-following hypothesis' more relevant than the aforementioned 'supply leading hypothesis'.

This paper aims to make an empirical reassessment of the finance-growth nexus in the age of financialisation by performing a panel data econometric analysis for EU countries from 1990 to 2016. This paper introduces at least seven novelties to the literature, namely by analysing EU countries; performing a panel data econometric analysis; incorporating the period before, during and after the crisis; assessing both the linear and non-linear effects of finance on economic growth; taking into account the potential endogeneity between finance and economic growth; examining the robustness of our results using different proxies for finance; and incorporating other control variables that are recognised as important drivers of economic growth. 


\section{GROWTH MODELS AND HYPOTHESES}

In order to assess the finance-growth nexus, we estimate a linear growth model based on Robert G. King and Ross Levine's (1993) version of the Robert J. Barro's (1991) growth regression by including a measurement of finance, which has the following form:

$$
Y_{i, t}=\beta_{0}+\beta_{1} X_{i, t}+\beta_{2} F_{i, t}+u_{i, t}
$$

where $i$ is the country, $t$ is the time period (years), $Y$ is the growth rate of the real per capita gross domestic product ${ }^{2}, X$ is a set of control variables that have been shown both theoretically and empirically to be robust determinants of economic growth, $F$ is a measure of the importance of finance, and $u$ is the two-way error term component accounting for unobservable countryspecific effects and time-specific effects.

Considering also the aforementioned potentially non-linear relationship between finance and economic growth (Cecchetti and Kharroubi, 2012; Barajas, Chami and Yousefi, 2013; Dabla-Norris and Srivisal, 2013; Beck, Degryse and Kneer, 2014), our growth model is also estimated taking into account the following form:

$$
Y_{i, t}=\beta_{0}+\beta_{1} X_{i, t}+\beta_{2} F_{i, t}+\beta_{3} F_{i, t}^{2}+u_{i, t}
$$

This approach allows us to identify the peak of the inverted U-shape (i.e. the turning point) through which the positive effect of finance starts to diminish by exerting a negative influence on growth. The turning point of finance $-F^{*}-$ can be obtained directly by the estimated coefficients, namely by determining the maximum of this concave quadratic function on the relationship between finance and growth, namely:

$$
\left(\beta_{2} F_{i, t}+\beta_{3} F_{i, t}^{2}\right)^{\prime}=0 \Leftrightarrow \beta_{2}+2 \beta_{3} F_{i, t}^{*}=0 \Leftrightarrow F_{i, t}^{*}=\frac{-\beta_{2}}{2 \beta_{3}}
$$

In both growth models (linear and non-linear one), our set of control variables encompasses the lagged growth rate of the real per capita gross domestic product, the inflation rate, the general government consumption, the degree of trade openness and the education level

\footnotetext{
2 Note that we use the growth rate of the real per capita gross domestic product instead of the growth rate of the real gross domestic product as a proxy of economic growth in order to consider not only the investors' prospects but also the people's prosperity (Alexiou, Vogiazas and Nellis, 2018). This is a common strategy in the majority of empirical studies around the finance-growth nexus (Rioja and Valev, 2003; Rousseau and Wachtel, 2011; Hassan, Sanchez and Yu, 2011; Beck, Degryse and Kneer, 2014; Khoutem B. Jedidia, Thouraya Boujelbène and Kamel Helali, 2014; Breitenlechner, Gächter and Sindermann, 2015; Durusu-Ciftci, Ispir and Yetkiner, 2017; Ehigiamusoe and Lean, 2017; Alexiou, Vogiazas and Nellis 2018).
}

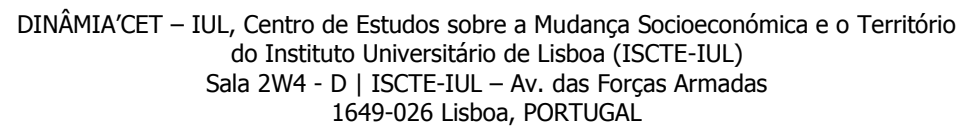


of the population. A similar set with these control variables was also used by Rioja and Valev (2004), M. Kabir Hassan, Benito Sanchez and Jung-Suk Yu (2011), Rousseau and Wachtel (2011), Cecchetti and Kharroubi (2012), Beck, Degryse and Kneer (2014), Breitenlechner, Gächter and Sindermann (2015) and Ehigiamusoe and Lean (2017).

The lagged value of the dependent variable was included in our growth models in order to take into account the steady-state convergence predicted by the neoclassical growth model (Hassan, Sanchez and Yu, 2011; Alexiou, Vogiazas and Nellis, 2018). As such, a positive effect of the lagged dependent variable on economic growth is expected.

The inflation rate is expected to exert a negative impact on economic growth, reflecting the level of uncertainty represented by price variability (Barro, 2003). This disruptive relationship between inflation and economic growth can also be explained through the decrease in investment, savings and capital accumulation in periods of high inflation (Stanley Fischer, 1993). The inclusion of the inflation rate also proxies the institutional development (Gunther Schnabl, 2009; Alexiou, Vogiazas and Nellis, 2018).

The general government consumption is expected to impact positively following the Keynesian argument that higher government spending stimulates aggregate demand, representing therefore an important motor for economic growth (Philip Arestis and Malcolm Sawyer, 2005; Constantinos Alexiou and Joseph G. Nellis, 2013; Ehigiamusoe and Lean, 2017; Alexiou, Vogiazas and Nellis, 2018).

The degree of trade openness has a positive effect on economic growth through the. greater competition and technological progress that a higher level of trade openness tends to generate (L. Alan Winters, 2004; Ehigiamusoe and Lean, 2017; Alexiou, Vogiazas and Nellis, 2018).

Economic growth also depends positively on the education level of the population, reflecting the beneficial role that human capital can have on growth (Rousseau and Wachtel, 2011; Ehigiamusoe and Lean, 2017). 


\section{DATA}

We collected annual data from 1990 to 2016 for all countries of the EU, obtaining a panel data composed of a total of 28 cross-sectional units $(N=28)$ observed over time $(T=27)$. This is the span and the periodicity for which all data exists, which covers the years where the age of financialisation achieved more preponderance in the case of EU countries (van der Zwan, 2014).

In order to obtain a holistic picture of the finance-growth nexus, we chose to use a large set of proxies to capture the role of finance and verify if our results are robust to the proxy chosen. This is particularly relevant, considering that 'defining appropriate proxies for the degree of financial development is, indeed, one of the challenges faced by empirical researchers' (Sebastian Edwards, 1996). The traditional measures referred to in the theoretical and empirical literature around this subject are the money supply (Rioja and Valev, 2004a and 2004b; Hassan, Sanchez and Yu, 2011; Rousseau and Wachtel, 2011; Breitenlechner, Gächter and Sindermann, 2015; Ehigiamusoe and Lean, 2017; Alexiou, Vogiazas and Nellis, 2018), the domestic credit (Rioja and Valev, 2004a and 2004b; Hassan, Sanchez and Yu, 2011; Rousseau and Wachtel, 2011, Cecchetti and Kharroubi, 2012; Beck, Degryse and Kneer, 2014; Jedidia, Boujelbène and Helali, 2014; Breitenlechner, Gächter and Sindermann, 2015; Durusu-Ciftci, Ispir and Yetkiner, 2017; Ehigiamusoe and Lean, 2017; Alexiou, Vogiazas and Nellis, 2018), the financial value added (Beck, Degryse and Kneer, 2014), the real interest rates (Alexiou, Vogiazas and Nellis, 2018), the stock market total volume traded (Jedidia, Boujelbène and Helali, 2014; Durusu-Ciftci, Ispir and Yetkiner, 2017; Alexiou, Vogiazas and Nellis, 2018) and the stock market capitalisation (Alexiou, Vogiazas and Nellis, 2018). These measures tend to capture different dimensions of finance, namely the financial depth, the overall size of financial intermediation activity and their corresponding efficiency (Beck, Degryse and Kneer, 2014; Breitenlechner, Gächter and Sindermann, 2015). In order to avoid multicollinearity problems, these measures will be used separately from each other.

It is worth noting that the available data for these different proxies of finance differ slightly according to the respective variable, but in all cases it was impossible to collect data for all the years for each country. Against this backdrop, seven unbalanced panels were constructed. The structure and composition of our seven unbalanced panels are illustrated in Table 1. 
The finance-growth nexus in the age of financialisation: An empirical reassessment for the European Union countries

Table 1 - Sample composition of each unbalanced panel

\begin{tabular}{|c|c|c|c|c|c|c|c|}
\hline Country & $\begin{array}{l}\text { Money } \\
\text { Supply }\end{array}$ & $\begin{array}{c}\text { Domestic } \\
\text { Credit }\end{array}$ & $\begin{array}{c}\text { Financial } \\
\text { Value Added }\end{array}$ & $\begin{array}{c}\text { Short-term } \\
\text { Interest Rate }\end{array}$ & $\begin{array}{c}\text { Long-term } \\
\text { Interest Rate }\end{array}$ & $\begin{array}{c}\text { Stock Market } \\
\text { Volume } \\
\text { Traded }\end{array}$ & $\begin{array}{l}\text { Stock Market } \\
\text { Capitalization }\end{array}$ \\
\hline Austria & $1990-2015$ & $2001-2016$ & $1995-2016$ & $1990-2016$ & $1990-2016$ & $1990-2015$ & $1990-2015$ \\
\hline Belgium & $1990-2015$ & $2001-2015$ & $1995-2015$ & $1990-2015$ & $1990-2015$ & $1990-2014$ & $1990-2015$ \\
\hline Bulgaria & $1991-2015$ & $2001-2016$ & $1999-2016$ & $1998-2016$ & $2002-2016$ & $1997-2013$ & 1993-2012 \\
\hline Cyprus & $1990-2015$ & $2005-2015$ & $1995-2015$ & $1999-2015$ & $1997-2015$ & $1992-2015$ & $1992-2015$ \\
\hline Czech Republic & $1994-2015$ & $2001-2015$ & $1995-2015$ & $1994-2015$ & $2001-2015$ & $1994-2014$ & $1994-2012$ \\
\hline Denmark & $1990-2015$ & 2001-2016 & $1990-2016$ & $1990-2016$ & $1990-2016$ & $1990-2012$ & $1990-2012$ \\
\hline Estonia & $2004-2015$ & 2004-2015 & $1996-2015$ & $1996-2015$ & $1998-2010$ & $1998-2012$ & $1998-2012$ \\
\hline Finland & $1990-2015$ & $2001-2016$ & $1990-2016$ & $1990-2016$ & $1990-2016$ & $1990-2012$ & $1990-2012$ \\
\hline France & $1990-2015$ & $2001-2015$ & $1990-2015$ & $1990-2015$ & $1990-2015$ & $1990-2014$ & $1990-2015$ \\
\hline Germany & $1992-2015$ & 2001-2015 & $1995-2015$ & $1992-2015$ & $1992-2015$ & $1992-2015$ & $1992-2015$ \\
\hline Greece & $1990-2015$ & 2001-2015 & $1995-2015$ & $1990-2015$ & $1992-2015$ & $1990-2015$ & $1990-2015$ \\
\hline Hungary & $1992-2015$ & $2001-2016$ & $1995-2016$ & $1994-2016$ & $1999-2016$ & $1992-2015$ & $1992-2015$ \\
\hline Ireland & $1990-2015$ & $2001-2016$ & $1995-2016$ & $1990-2016$ & $1990-2016$ & $1995-2015$ & $1996-2014$ \\
\hline Italy & $1990-2015$ & 2001-2015 & $1995-2015$ & $1990-2015$ & $1990-2015$ & $1990-2014$ & $1990-2014$ \\
\hline Latvia & $1996-2015$ & $2010-2015$ & $1996-2015$ & $1996-2015$ & $2001-2015$ & $1996-2012$ & $1996-2012$ \\
\hline Lithuania & $1996-2015$ & 2010-2016 & $1996-2016$ & $1999-2016$ & $2001-2016$ & $1996-2012$ & $1996-2012$ \\
\hline Luxembourg & $1992-2011$ & $2001-2015$ & $1995-2015$ & $1999-2015$ & $1992-2015$ & $1992-2015$ & $1992-2015$ \\
\hline Malta & $1990-2015$ & $2005-2016$ & $1995-2016$ & $1995-2016$ & $2000-2016$ & $1996-2015$ & $1995-2015$ \\
\hline Netherlands & $1990-2015$ & $2001-2016$ & $1995-2016$ & $1990-2016$ & $1990-2016$ & $1990-2014$ & $1990-2015$ \\
\hline Norway & $1990-2015$ & $1990-2016$ & $1990-2015$ & $1990-2012$ & $1990-2010$ & $1990-2015$ & $1990-2015$ \\
\hline Poland & 1991-2015 & $2001-2016$ & $1995-2016$ & $1995-2016$ & $1999-2016$ & $1991-2015$ & $1992-2015$ \\
\hline Portugal & $1990-2015$ & $2001-2016$ & $1995-2016$ & $1990-2016$ & $1990-2016$ & $1990-2014$ & $1990-2015$ \\
\hline Romania & $1991-2013$ & 1991-2016 & $1995-2016$ & $1995-2016$ & 2006-2016 & $1995-2012$ & $1995-2012$ \\
\hline Slovakia & $2002-2015$ & $2006-2015$ & $1995-2015$ & $1995-2015$ & $2000-2015$ & $1994-2013$ & $1994-2013$ \\
\hline Slovenia & 1996-2015 & $2005-2015$ & 1996-2015 & $1998-2015$ & $2002-2015$ & $1996-2015$ & $1996-2015$ \\
\hline Spain & $1990-2015$ & 2001-2016 & $1995-2016$ & $1990-2016$ & $1990-2016$ & $1990-2015$ & $1990-2015$ \\
\hline Sweden & $1990-2015$ & $2001-2015$ & $1993-2015$ & $1990-2015$ & $1990-2015$ & $1990-2012$ & $1990-2012$ \\
\hline United Kingdom & $1990-2015$ & $1990-2015$ & $1995-2015$ & $1990-2015$ & $1990-2015$ & $1990-2014$ & $1990-2012$ \\
\hline Observations & 665 & 428 & 615 & 653 & 599 & 630 & 631 \\
\hline Missing Values & 91 & 328 & 141 & 103 & 157 & 126 & 125 \\
\hline
\end{tabular}

Table 2 contains the proxies used for each variable and the respective sources and Table 3 contains the descriptive statistics for each one. Figures A1 to A12 in the Appendix represent the respective plots.

Table 2 - The proxies and sources of each variable

\begin{tabular}{c|c|c}
\hline Variable & Proxy & Source \\
\hline Growth & GDP per capita growth (annual \%) & World Bank \\
Inflation & Inflation, consumer prices (annual \%) & World Bank \\
Government Consumption & General government final consumption expenditure (\% of GDP) & World Bank \\
Trade Openness & Exports and imports of goods and services (\% of GDP) & World Bank \\
Education & School enrollment, secondary (\% gross) & World Bank \\
Money Supply & Liquid liabilities (\% of GDP) & Fred St. Louis \\
Domestic Credit & Domestic credit provided by financial sector (\% of GDP) & World Bank \\
Financial Value Added & Gross value added of financial activities s $^{\text {( } \% \text { of total) }}$ & Eurostat \\
Short-term Interest Rate & Real short-term interest rates, deflator GDP (\%) & AMECO \\
Long-term Interest Rate & Real long-term interest rates, deflator GDP (\%) & AMECO \\
Stock Market Volume Traded & The stock market total volume traded (\% of GDP) & Fred St. Louis \\
Stock Market Capitalization & Stock market capitalization (\% of GDP) & Fred St. Louis \\
\hline
\end{tabular}

${ }^{3}$ Financial activities correspond to the ones that are classified into category $\mathrm{K}$ and $\mathrm{L}$ according to the second revision of NACE. They encompass financial, insurance and real estate activities.

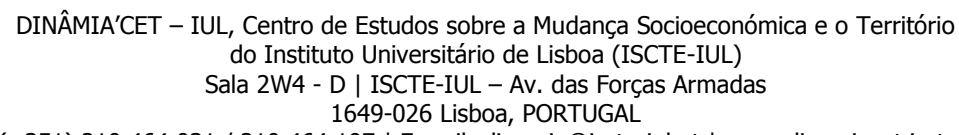


The finance-growth nexus in the age of financialisation:

An empirical reassessment for the European Union countries

Table 3 - The descriptive statistics of each variable

\begin{tabular}{|c|c|c|c|c|c|}
\hline Variable & Mean & Median & Maximum & Minimum & $\begin{array}{l}\text { Standard } \\
\text { Deviation }\end{array}$ \\
\hline Growth & 0.022 & 0.022 & 0.244 & -0.146 & 0.036 \\
\hline Inflation & 0.081 & 0.025 & 10.584 & -0.045 & 0.459 \\
\hline Government Consumption & 0.197 & 0.194 & 0.279 & 0.116 & 0.029 \\
\hline Trade Openness & 1.034 & 0.863 & 4.102 & 0.340 & 0.588 \\
\hline Education & 1.045 & 1.010 & 1.639 & 0.597 & 0.163 \\
\hline Money Supply & 0.819 & 0.657 & 3.991 & 0.158 & 0.559 \\
\hline Domestic Credit & 1.198 & 1.159 & 3.166 & 0.128 & 0.604 \\
\hline Financial Value Added & 0.147 & 0.139 & 0.385 & 0.081 & 0.048 \\
\hline Short-term Interest Rate & 0.016 & 0.012 & 0.252 & -0.232 & 0.038 \\
\hline Long-term Interest Rate & 0.028 & 0.025 & 0.244 & -0.124 & 0.033 \\
\hline Stock Market Volume Traded & 0.321 & 0.132 & 2.500 & 0.000 & 0.426 \\
\hline Stock Market Capitalization & 0.342 & 0.342 & 2.500 & 0.000 & 0.402 \\
\hline
\end{tabular}

\section{ECONOMETRIC METHODOLOGY}

Our growth models are estimated using the LSDVBC estimator follow the 'xtlsdvc' command in the Stata software. The LSDVBC estimator was introduced by Stephen Nickel (1981), Jan F. Kiviet (1995) and Maurice Bun and Jan F. Kiviet (2003) and it was extended by Giovanni Bruno (2005a and 2005b) for the case of unbalanced panels. This is the only existing estimator that can produce reliable estimates taking into account that we have a dynamic panel data model due to the inclusion of the lagged growth rate among the control variables, an unbalanced panel due to the presence of some missing values in our sample, a macro panel due to the relatively small cross-sectional dimension $N$ of our sample and the possible existence of endogeneity due to the aforementioned potential reverse causation between finance and growth in the wake of the 'demand-following hypothesis'.

We can appoint two specific sets of reasons to validate the adequacy of the LSDVBC estimator to produce our estimates. Firstly, the standard panel data estimators (e.g. pooled ordinary least squares, least-squares dummy variables, fixed effects and random effects) produce biased and/or inconsistent estimates because the lagged dependent variable is correlated with fixed effects in the error term (Nickel, 1981; Baltagi, 2005; A. Colin Cameron and Pravin K. Trivedi, 2009; among others) and the standard panel data estimators for dynamic panel data models (e.g. T. W. Anderson and Cheng Hsiao, 1982; Manuel Arrelano and Stephen Bond, 1991; Manuel Arrelano and Olympia Bover, 1995; and Richard Blundell and Stephen Bond, 1998) produce severely biased and imprecise estimates in the presence of macro panels with a moderate cross-sectional dimension $N$ (Bruno, 2005a and 2005b). Secondly, Monte Carlo evidence has concluded the superiority of the LSDVBC estimator vis-à-vis the former estimators in terms of bias and efficiency in the cases of macro panels (Kiviet, 1995; Ruth A. Judson and Ann L. Owen, 1999; and Bruno, 2005a and 2005b) and the good performance of the LSDVBC estimator also in the cases where endogeneity can exist (Andreas Behr, 2003).

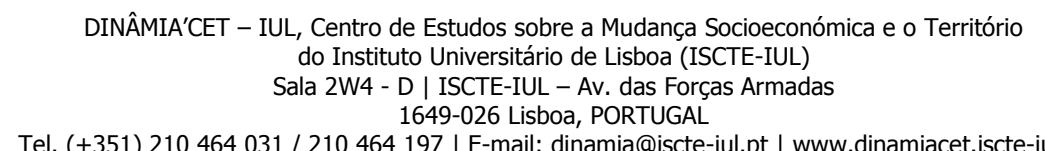

Tel. (+351) 210464031 / 210464197 | E-mail: dinamia@iscte-iul.pt | www.dinamiacet.iscte-iul.pt 
The implementation of the LSDVBC estimator involves two different stages (Bruno, 2005a and 2005b). Firstly, the LSDVBC estimator produces consistent estimates. This forces the definition of an initial matrix of starting values, which can be achieved through three different consistent estimators (Anderson and Hsiao, 1982; Arrelano and Bond, 1991; and Blundell and Bond, 1998). However, the results are quite robust to the choice of one of these three different estimators (Maurice Bun and Jan F. Kiviet, 2001; and Bruno, 2005a and 2005b). Secondly, the LSDVBC estimator corrects the bias by producing a set of multiple replications to bootstrap the standard errors.

In what follows, the estimates are presented, which are produced by using the Arrelano and Bond estimator to initialise the LSDVBC estimator and a number of replications equal to 250. We also include time dummies in our estimates and the respective WALD test to evaluate their statistical significance.

\section{EMPIRICAL FINDINGS}

\subsection{LINEAR GROWTH MODEL}

We start by presenting the results of our estimates for the linear growth model for all years and all countries. The respective results are presented in Table 4. Six conclusions should be addressed. Firstly, our results corroborate the hypothesis on the steady-state convergence predicted by the neoclassical growth model, as in Hassan, Sanchez and Yu (2011), Breitenlechner, Gächter and Sindermann (2015) and Alexiou, Vogiazas and Nellis (2018). Secondly and also as expected, the inflation rate exerts an adverse effect on economic growth on the EU countries due to the corresponding distortion on the allocation of resources that price variability tends to have. This result was also found by Rioja and Valev (2004a and 2004b), Hassan, Sanchez and Yu (2011), Breitenlechner, Gächter and Sindermann (2015) and Ehigiamusoe and Lean (2017). Thirdly, general government consumption has a harmful impact on the economic growth of the EU countries, which does not support the Keynesian argument that higher government spending stimulates aggregate demand. According to Alexiou, Vogiazas and Nellis (2018), this result can be explained from a demand-side perspective and a supplyside perspective. From a demand-side perspective, higher government spending could impact economic growth negatively by representing a source of inflation pressures. From a supply-side perspective, higher government spending could impact economic growth negatively due to high

\footnotetext{
DINÂMIA'CET - IUL, Centro de Estudos sobre a Mudança Socioeconómica e o Território do Instituto Universitário de Lisboa (ISCTE-IUL)

Sala 2W4 - D | ISCTE-IUL - Av. das Forças Armadas 1649-026 Lisboa, PORTUGAL

Tel. (+351) 210464031 / 210464197 | E-mail: dinamia@iscte-iul.pt | www.dinamiacet.iscte-iul.pt
} 
public sector wages, inefficient State enterprises, high level of corruption, among other phenomena. A disruptive relationship between general government consumption and economic growth was also encountered by other empirical studies on this subject (Rioja and Valev, 2004a and 2004b; Hassan, Sanchez and Yu, 2011; Rousseau and Wachtel, 2011; Cecchetti and Kharroubi, 2012; and Breitenlechner, Gächter and Sindermann, 2015). Fourthly, trade openness is statistically significant and has the expected positive sign, confirming its positive effect on the economic growth of EU countries. This is a common result of empirical studies on the financegrowth nexus. Fifthly, the education level of the population does not affect the economic growth of the EU countries due to its statistical insignificance at traditional significance levels. Given that the education level of the population remained relatively stable in our sample (Figure A5 in the Appendix), its lack of statistical significance is not too surprising. Note that this result does not change if we had used primary school enrolment instead of secondary school enrolment ${ }^{4}$. Sixthly and foremost, our results do not confirm the finance-growth nexus hypothesis. Effectively, the majority of proxies for finance are statistically significant at traditional significance levels and exhibit negative coefficients, which corroborates that finance impairs economic growth in EU countries in the age of financialisation, as recognised by Aghion, Howitt and Mayer-Foulkes (2005), Kose et al. (2006), Prasad, Rajan and Subramanian (2007), Rousseau and Wachtel (2011), Cecchetti and Kharroubi (2012), Barajas, Chami and Yousefi (2013), Dabla-Norris and Srivisal (2013), Beck, Degryse and Kneer (2014), Breitenlechner, Gächter and Sindermann (2015), Ehigiamusoe and Lean (2017) and Alexiou, Vogiazas and Nellis (2018). Even so, the proxies linked with stock markets (i.e. the stock market volume traded and stock market capitalisation) are not statistically significant at conventional significance levels, which indicates that they do not cause any impact on economic growth in the EU countries. This result is not so surprising taking into account that the majority of the EU countries are 'bank-based' and not 'market-based' (Jakob de Haan, Sander Oosterloo and Dirk Schoenmaker, 2015), which means that the role of finance in the intermediation process between savings and investments occurs essentially through banking activity.

\footnotetext{
${ }^{4}$ Results available upon request.

DINÂMIA'CET - IUL, Centro de Estudos sobre a Mudança Socioeconómica e o Território

do Instituto Universitário de Lisboa (ISCTE-IUL)

Sala 2W4 - D | ISCTE-IUL - Av. das Forças Armadas 1649-026 Lisboa, PORTUGAL 
Table 4 - Estimates of the linear growth model for the full period (1990-2016)

\begin{tabular}{|c|c|c|c|c|c|c|c|}
\hline Variable & $\begin{array}{l}\text { Money } \\
\text { Supply }\end{array}$ & $\begin{array}{c}\text { Domestic } \\
\text { Credit }\end{array}$ & $\begin{array}{c}\text { Financial } \\
\text { Value Added }\end{array}$ & $\begin{array}{c}\text { Short-term } \\
\text { Interest Rate }\end{array}$ & $\begin{array}{c}\text { Long-term } \\
\text { Interest Rate }\end{array}$ & $\begin{array}{c}\text { Stock Market } \\
\text { Volume } \\
\text { Traded }\end{array}$ & $\begin{array}{l}\text { Stock Market } \\
\text { Capitalization }\end{array}$ \\
\hline \multirow{4}{*}{ Growth $_{t-1}$} & $0.472 * * *$ & $0.383 * * *$ & 0.395 *** & $0.343^{* * * *}$ & $0.315^{* * * *}$ & $0.442 * * *$ & $0.466 * * *$ \\
\hline & $(0.040)$ & $(0.056)$ & $(0.042)$ & $(0.037)$ & $(0.039)$ & $(0.045)$ & $(0.045)$ \\
\hline & [11.78] & [6.83] & [9.43] & [9.17] & [8.12] & {$[9.76]$} & {$[10.27]$} \\
\hline & $-0.006 * * *$ & $-0.016^{*}$ & $-0.071 * * *$ & $-0.098 * * *$ & $-0.215^{* * *}$ & $-0.057 * * *$ & $-0.007 * * *$ \\
\hline \multirow{2}{*}{ Inflation $_{t}$} & $(0.002)$ & $(0.009)$ & $(0.015)$ & $(0.014)$ & $(0.054)$ & $(0.014)$ & $(0.002)$ \\
\hline & {$[-2.92]$} & {$[-1.76]$} & {$[-4.73]$} & {$[-6.83]$} & {$[-3.96]$} & {$[-3.96]$} & {$[-3.68]$} \\
\hline \multirow{4}{*}{$\begin{array}{c}\text { Government } \\
\text { Consumption }_{t}\end{array}$} & $-0.133^{*}$ & -0.144 & $-0.145^{*}$ & -0.144 & $-0.200^{* *}$ & $-0.155^{*}$ & -0.116 \\
\hline & $(0.071)$ & $(0.133)$ & $(0.078)$ & $(0.078)$ & $(0.085)$ & $(0.082)$ & $(0.072)$ \\
\hline & {$[-1.88]$} & {$[-1.09]$} & {$[-1.86]$} & {$[-1.46]$} & {$[-2.35]$} & {$[-1.88]$} & {$[-1.60]$} \\
\hline & $0.016^{* *}$ & $0.023^{* *}$ & $0.014 *$ & $0.024 * * *$ & $0.015^{* * *}$ & $0.016^{* *}$ & $0.014 * *$ \\
\hline \multirow[t]{3}{*}{ Trade Openness $_{t}$} & $(0.007)$ & $(0.012)$ & $(0.008)$ & $(0.007)$ & $(0.005)$ & $(0.006)$ & $(0.006)$ \\
\hline & {$[2.23]$} & [2.00] & [1.83] & [3.23] & [2.71] & [2.44] & [2.28] \\
\hline & 0.003 & 0.015 & 0.015 & -0.003 & 0.006 & 0.005 & 0.001 \\
\hline \multirow[t]{3}{*}{ Education $_{t}$} & $(0.012)$ & $(0.020)$ & $(0.015)$ & $(0.012)$ & $(0.011)$ & $(0.013)$ & $(0.013)$ \\
\hline & {$[0.26]$} & {$[0.75]$} & {$[0.99]$} & {$[-0.25]$} & {$[0.53]$} & {$[0.40]$} & {$[0.11]$} \\
\hline & -0.009 & $-0.018 * * *$ & $-0.230 * * *$ & $-0.229 * * *$ & $-0.312 * * *$ & 0.008 & 0.005 \\
\hline \multirow[t]{2}{*}{ Finance $_{t}$} & $(0.008)$ & $(0.008)$ & $(0.071)$ & $(0.035)$ & $(0.037)$ & $(0.005)$ & $(0.005)$ \\
\hline & {$[-1.13]$} & {$[-2.19]$} & {$[-3.25]$} & {$[-6.55]$} & {$[-8.47]$} & [1.46] & {$[0.86]$} \\
\hline Observations & 609 & 372 & 559 & 597 & 543 & 574 & 575 \\
\hline Groups & 28 & 28 & 28 & 28 & 28 & 28 & 28 \\
\hline Time Effects & Yes & Yes & Yes & Yes & Yes & Yes & Yes \\
\hline P-value Wald Test & $0.000 * * *$ & $0.000 * * *$ & $0.000 * * *$ & $0.000 * * *$ & $0.000 * * *$ & $0.000 * * *$ & $0.000 * * *$ \\
\hline
\end{tabular}

Note: Standard errors in ( ), Z-statistics in [], *** indicates statistical significance at $1 \%$ level, ** indicates statistical significance at 5\% level and * indicates statistical significance at $10 \%$ level. Coefficients, standard errors and z-statistics for the year dummies are not reported

As the Great Recession represented a strong negative shock in EU countries (Figure A1 in the Appendix), we also present the results of our estimates for the linear growth model for all countries for both pre-crisis and crisis and post-crisis periods, respectively. The corresponding results are presented in Table 5 and Table 6. Nonetheless, these results do not differ substantially in comparison with the results for the full period. In the pre-crisis period, the variables that are statistically significant are exactly the same as in the full period and they have the same effects on the economic growth of EU countries. This is probably because the precrisis period represents the highest proportion of the total span in our sample. In fact, the lagged growth rate of the real per capita gross domestic product and trade openness remain positive determinants of economic growth in EU countries, whilst the inflation rate, the general government consumption and finance persist as negative determinants of economic growth in EU countries. In the crisis and the post-crisis periods, the most important change is related to the variable of inflation rate, which loses its statistical significance. As stressed by Alexiou, Vogiazas and Nellis (2018), this is an expected result given the relatively stable inflation environment during that period in the EU countries (Figure A2 in the Appendix). The remaining variables do not change in terms of statistical significance and signs in comparison with the full period and the pre-crisis period, respectively. It is still worth noting that the magnitude of the coefficients for the proxies of finance is higher in the crisis and post-crisis periods than in the pre-crisis period. This can reveal that the prejudicial effects of finance on economic growth are became worse in recent years in EU countries.

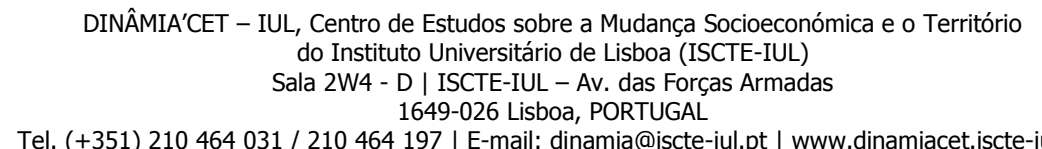


The finance-growth nexus in the age of financialisation:

An empirical reassessment for the European Union countries

Table 5 - Estimates of the linear growth model for the pre-crisis period (1990-2008)

\begin{tabular}{|c|c|c|c|c|c|c|c|}
\hline Variable & $\begin{array}{l}\text { Money } \\
\text { Supply }\end{array}$ & $\begin{array}{l}\text { Domestic } \\
\text { Credit }\end{array}$ & $\begin{array}{c}\text { Financial } \\
\text { Value Added }\end{array}$ & $\begin{array}{l}\text { Short-term } \\
\text { Interest Rate }\end{array}$ & $\begin{array}{c}\text { Long-term } \\
\text { Interest Rate }\end{array}$ & $\begin{array}{c}\text { Stock Market } \\
\text { Volume } \\
\text { Traded }\end{array}$ & $\begin{array}{l}\text { Stock Market } \\
\text { Capitalization }\end{array}$ \\
\hline \multirow{4}{*}{ Growth $_{t-1}$} & $0.471 * * *$ & $0.406^{* * *}$ & $0.337 * * *$ & $0.321 * * *$ & $0.318 * * *$ & $0.358 * * *$ & $0.474 * * *$ \\
\hline & $(0.047)$ & $(0.082)$ & $(0.050)$ & $(0.046)$ & $(0.054)$ & $(0.048)$ & $(0.054)$ \\
\hline & [9.99] & [4.97] & {$[6.70]$} & [6.95] & [5.89] & [7.51] & [8.71] \\
\hline & $-0.007 * *$ & $-0.032 * * *$ & $-0.110^{* * *}$ & $-0.121 * * *$ & $-0.255^{* * *}$ & $-0.084 * * *$ & $-0.008 * * *$ \\
\hline \multirow[t]{2}{*}{ Inflation $_{t}$} & $(0.002)$ & $(0.009)$ & $(0.013)$ & $(0.013)$ & $(0.053)$ & $(0.012)$ & $(0.002)$ \\
\hline & {$[-3.57]$} & {$[-3.36]$} & {$[-8.60]$} & {$[-9.17]$} & {$[-4.79]$} & {$[-7.15]$} & {$[-4.10]$} \\
\hline \multirow{4}{*}{$\begin{array}{l}\text { Government } \\
\text { Consumption }_{t}\end{array}$} & -0.129 & $-0.407 * *$ & $-0.413 * * *$ & $-0.309 * * *$ & $-0.460 * * *$ & $-0.227 * * *$ & $-0.152 *$ \\
\hline & $(0.087)$ & $(0.181)$ & (0.097) & $(0.083)$ & $(0.109)$ & $(0.085)$ & $(0.080)$ \\
\hline & {$[-1.48]$} & {$[-2.25]$} & {$[-4.26]$} & {$[-3.71]$} & {$[-4.23]$} & {$[-1.98]$} & {$[-1.90]$} \\
\hline & 0.009 & 0.009 & $0.019 * *$ & $0.031 * * *$ & $0.019 * * *$ & $0.016^{* *}$ & 0.012 \\
\hline \multirow[t]{3}{*}{ Trade Openness $t_{t}$} & $(0.007)$ & $(0.019)$ & $(0.009)$ & $(0.009)$ & $(0.007)$ & $(0.008)$ & $(0.008)$ \\
\hline & {$[1.26]$} & {$[0.46]$} & {$[2.23]$} & [3.28] & [2.66] & [1.98] & {$[1.58]$} \\
\hline & 0002 & 0.027 & 0.016 & -0.006 & -0.009 & 0.003 & 0.002 \\
\hline \multirow{3}{*}{ Education $_{t}$} & $(0.014)$ & $(0.032)$ & $(0.06)$ & $(0.013)$ & $(0.012)$ & $(0.014)$ & $(0.014)$ \\
\hline & {$[0.12]$} & {$[0.85]$} & [1.01] & {$[-0.42]$} & -0.69 & [0.19] & {$[0.15]$} \\
\hline & -0.013 & $-0.019 *$ & -0.159 & $-0.115^{* * *}$ & -0.050 & 0.007 & 0.007 \\
\hline \multirow{2}{*}{ Finance $_{t}$} & $(0.009)$ & $(0.011)$ & $(0.101)$ & $(0.036)$ & $(0.053)$ & (0.004) & $(0.006)$ \\
\hline & {$[-1.42]$} & {$[-1.68]$} & {$[-1.58]$} & {$[-3.18]$} & {$[-0.95]$} & {$[1.50]$} & {$[1.14]$} \\
\hline Observations & 419 & 168 & 350 & 391 & 344 & 410 & 413 \\
\hline Groups & 28 & 26 & 28 & 28 & 28 & 28 & 28 \\
\hline Time Effects & Yes & Yes & Yes & Yes & Yes & Yes & Yes \\
\hline P-value Wald Test & $0.000 * * *$ & $0.000 * * *$ & $0.000^{* * * *}$ & $0.000^{* * * *}$ & $0.000^{* * *}$ & $0.000^{* * *}$ & $0.000 * * *$ \\
\hline
\end{tabular}

Note: Standard errors in ( ), Z-statistics in [], *** indicates statistical significance at $1 \%$ level, ** indicates statistical significance at 5\% level and * indicates statistical significance at $10 \%$ level. Coefficients, standard errors and z-statistics for the year dummies are not reported

Table 6 - Estimates of the linear growth model for the crisis and post-crisis periods (2009-2016)

\begin{tabular}{|c|c|c|c|c|c|c|c|}
\hline Variable & $\begin{array}{l}\text { Money } \\
\text { Supply }\end{array}$ & $\begin{array}{c}\text { Domestic } \\
\text { Credit }\end{array}$ & $\begin{array}{c}\text { Financial } \\
\text { Value Added }\end{array}$ & $\begin{array}{c}\text { Short-term } \\
\text { Interest Rate }\end{array}$ & $\begin{array}{c}\text { Long-term } \\
\text { Interest Rate }\end{array}$ & $\begin{array}{c}\text { Stock Market } \\
\text { Volume } \\
\text { Traded }\end{array}$ & $\begin{array}{l}\text { Stock Market } \\
\text { Capitalization }\end{array}$ \\
\hline \multirow{4}{*}{ Growth $_{t-1}$} & $0.334 * * *$ & 0.086 & $0.126^{* *}$ & 0.079 & -0.055 & $0.380^{* * * *}$ & $0.372 * * *$ \\
\hline & $(0.055)$ & $(0.076)$ & $(0.060)$ & $(0.062)$ & $(0.059)$ & $(0.069)$ & $(0.042)$ \\
\hline & [6.09] & {$[1.14]$} & {$[2.10]$} & {$[1.27]$} & {$[-0.92]$} & {$[5.47]$} & [8.91] \\
\hline & -0.152 & 0.016 & -0.218 & -0.082 & -0.235 & -0.285 & $-0.446 * *$ \\
\hline \multirow[t]{2}{*}{ Inflation $_{t}$} & $(0.185)$ & $(0.197)$ & $(0.184)$ & $(0.165)$ & $(0.185)$ & $(0.214)$ & $(0.187)$ \\
\hline & {$[-0.82]$} & {$[0.08]$} & {$[-1.18]$} & {$[-0.50]$} & {$[-1.27]$} & {$[-1.33]$} & {$[-2.39]$} \\
\hline \multirow{4}{*}{$\begin{array}{l}\text { Government } \\
\text { Consumption }_{t}\end{array}$} & $-1.500 * * *$ & $-0.842 * * *$ & $-1.315^{* * *}$ & $-1.246 * * *$ & $-1.315^{* * *}$ & $-1.828 * * *$ & $-1.210 * * *$ \\
\hline & $(0.315)$ & $(0.264)$ & $(0.259)$ & $(0.244)$ & $(0.234)$ & $(0.316)$ & $(0.316)$ \\
\hline & {$[-4.75]$} & {$[-3.19]$} & {$[-5.08]$} & {$[-5.11]$} & {$[-5.63]$} & {$[-5.78]$} & {$[-3.83]$} \\
\hline & $0.088 * * *$ & $0.033^{*}$ & $0.045^{* *}$ & 0.035 ** & 0.027 & $0.051 * *$ & $0.052 * *$ \\
\hline \multirow{3}{*}{ Trade Openness } & $(0.033)$ & $(0.020)$ & $(0.020)$ & $(0.017)$ & $(0.018)$ & $(0.025)$ & $(0.021)$ \\
\hline & {$[2.66]$} & [1.66] & [2.32] & [2.07] & [1.53] & {$[2.04]$} & {$[2.45]$} \\
\hline & 0.029 & 0.010 & 0.044 & 0.025 & 0.030 & -0.049 & -0.053 \\
\hline \multirow[t]{3}{*}{ Education $_{t}$} & $(0.030)$ & $(0.029)$ & $(0.028)$ & $(0.026)$ & $(0.027)$ & $(0.051)$ & $(0.063)$ \\
\hline & [0.99] & {$[0.36]$} & {$[1.58]$} & {$[0.95]$} & [1.11] & {$[-0.96]$} & {$[-0.84]$} \\
\hline & 0.009 & $-0.038 * *$ & $-0.572 * * *$ & $-0.463 * * *$ & $-0.474 * * *$ & 0.010 & 0.014 \\
\hline \multirow[t]{2}{*}{ Finance $_{t}$} & $(0.032)$ & $(0.016)$ & $(0.212)$ & $(0.129)$ & $(0.084)$ & $(0.023)$ & $(0.020)$ \\
\hline & {$[0.28]$} & {$[-2.36]$} & {$[2.70]$} & {$[-3.59]$} & {$[-5.66]$} & {$[0.43]$} & {$[0.71]$} \\
\hline Observations & 134 & 152 & 153 & 150 & 143 & 108 & 106 \\
\hline Groups & 28 & 28 & 28 & 28 & 26 & 28 & 28 \\
\hline Time Effects & Yes & Yes & Yes & Yes & Yes & Yes & Yes \\
\hline P-value Wald Test & $0.000 * * *$ & $0.000 * * *$ & $0.000^{* * * *}$ & $0.000^{* * * *}$ & $0.000^{* * * *}$ & $0.000^{* * * *}$ & $0.000 * * *$ \\
\hline
\end{tabular}

Note: Standard errors in ( ), z-statistics in [], *** indicates statistical significance at $1 \%$ level, ** indicates statistical significance at $5 \%$ level and $*$ indicates statistical significance at $10 \%$ level. Coefficients, standard errors and z-statistics for the year dummies are not reported

\subsection{NON-LINEAR GROWTH MODEL}

Now, we present the results of our estimates for the non-linear growth model for all years and all countries, in order to assess whether there is an inverted U-shaped effect of finance on economic growth in the EU countries. The respective results are presented in Table 7. The most important finding is connected with the non-statistical significance of the squared term of finance, which suggests that there is not a concave quadratic relationship between finance and

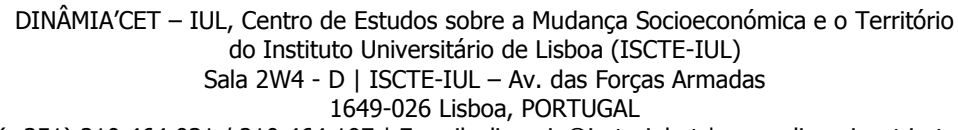


economic growth in the EU countries. The only exception is related to the proxy of domestic credit, for which the squared term is statistically significant at traditional significance levels. However, its positive coefficient suggests that the relationship between finance and economic growth is really convex instead of concave, which is associated with a turning point of around $233 \%$ of the gross domestic product. This seems to suggest that domestic credit in the EU countries needs to supplant this threshold to start to exert a positive impact on economic growth. The remaining variables maintain their statistical significance and the same sign in comparison with the estimates of the linear growth model, confirming the robustness of our results.

Table 7 - Estimates of the non-linear growth model for the full period (1990-2016)

\begin{tabular}{|c|c|c|c|c|c|c|c|}
\hline Variable & $\begin{array}{l}\text { Money } \\
\text { Supply }\end{array}$ & $\begin{array}{c}\text { Domestic } \\
\text { Credit }\end{array}$ & $\begin{array}{c}\text { Financial } \\
\text { Value Added }\end{array}$ & $\begin{array}{c}\text { Short-term } \\
\text { Interest Rate }\end{array}$ & $\begin{array}{c}\text { Long-term } \\
\text { Interest Rate }\end{array}$ & $\begin{array}{c}\text { Stock Market } \\
\text { Volume } \\
\text { Traded }\end{array}$ & $\begin{array}{l}\text { Stock Market } \\
\text { Capitalization }\end{array}$ \\
\hline \multirow{4}{*}{ Growth $_{t-1}$} & $0.471 * * *$ & $0.345^{* * *}$ & $0.394 * * *$ & $0.344^{*} * * *$ & $0.315^{* * *} *$ & 0.438 *** & $0.458 * * *$ \\
\hline & $(0.040)$ & $(0.057)$ & $(0.042)$ & $(0.037)$ & $(0.039)$ & $(0.046)$ & $(0.045)$ \\
\hline & [11.67] & {$[6.08]$} & {$[9.38]$} & {$[9.21]$} & {$[8.04]$} & {$[9.61]$} & {$[10.11]$} \\
\hline & $-0.006 * * *$ & $-0.015^{*}$ & -0.071 *** & -0.087 *** & $-0.211 * * *$ & $-0.058 * * *$ & $-0.007 * * *$ \\
\hline \multirow[t]{2}{*}{ Inflation $_{t}$} & $(0.002)$ & $(0.009)$ & $(0.015)$ & $(0.019)$ & $(0.057)$ & $(0.014)$ & $(0.002)$ \\
\hline & {$[-2.91]$} & {$[-1.71]$} & {$[-4.65]$} & {$[-4.64]$} & {$[-3.69]$} & {$[-4.02]$} & {$[-3.64]$} \\
\hline \multirow{4}{*}{$\begin{array}{c}\text { Government } \\
\text { Consumption }_{t}\end{array}$} & $-0.134 *$ & -0.209 & $-0.148^{*}$ & -0.119 & $-0.201 * *$ & $-0.152 *$ & -0.110 \\
\hline & $(0.071)$ & $(0.134)$ & $(0.080)$ & $(0.078)$ & $(0.085)$ & $(0.083)$ & $(0.073)$ \\
\hline & {$[-1.87]$} & {$[-1.56]$} & {$[-1.84]$} & {$[-1.52]$} & {$[-2.35]$} & {$[-1.84]$} & {$[-1.51]$} \\
\hline & $0.016 * *$ & $0.022 * *$ & $0.014 *$ & $0.023 * * *$ & $0.015^{* * *} *$ & $0.017 * * * *$ & $0.015 * *$ \\
\hline \multirow[t]{3}{*}{ Trade Openness $_{t}$} & $(0.007)$ & $(0.011)$ & $(0.008)$ & $(0.007)$ & $(0.005)$ & $(0.006)$ & $(0.006)$ \\
\hline & {$[2.16]$} & [1.96] & {$[1.75]$} & [3.19] & {$[2.70]$} & {$[2.63]$} & {$[2.37]$} \\
\hline & 0.003 & 0.003 & 0.015 & -0.022 & 0.006 & 0.005 & 0.002 \\
\hline \multirow[t]{3}{*}{ Education $_{t}$} & $(0.012)$ & $(0.020)$ & $(0.016)$ & (0.012 & $(0.011)$ & $(0.013)$ & $(0.013)$ \\
\hline & {$[0.27]$} & {$[0.78]$} & {$[0.98]$} & {$[-0.20]$} & {$[0.53]$} & {$[0.37]$} & [1.33] \\
\hline & -0.011 & $-0.070 * * *$ & -0.269 & $-0.208 * * *$ & $-0.302 * * *$ & $0.020^{*}$ & 0.017 \\
\hline \multirow[t]{3}{*}{ Finance $_{t}$} & $(0.013)$ & $(0.021)$ & $(0.228)$ & $(0.042)$ & $(0.053)$ & $(0.011)$ & $(0.013)$ \\
\hline & {$[-0.83]$} & [-3.39] & {$[-1.18]$} & {$[-4.99]$} & {$[-5.66]$} & {$[1.81]$} & [1.33] \\
\hline & 0.001 & $0.015 * * *$ & 0.123 & -0.259 & -0.096 & -0.006 & -0.006 \\
\hline \multirow{2}{*}{ Finance $_{t}{ }_{t}$} & $(0.003)$ & $(0.006)$ & $(0.627)$ & $(0.290)$ & $(0.339)$ & $(0.005)$ & $(0.005)$ \\
\hline & {$[0.21]$} & {$[2.65]$} & {$[0.20]$} & [0.89] & {$[-0.28]$} & {$[-1.30]$} & {$[-1.03]$} \\
\hline Finance* & n.a. & 233 & n.a. & n.a. & n.a. & n.a. & n.a. \\
\hline Observations & 609 & 372 & 559 & 597 & 543 & 574 & 575 \\
\hline Groups & 28 & 28 & 28 & 28 & 28 & 28 & 28 \\
\hline Time Effects & Yes & Yes & Yes & Yes & Yes & Yes & Yes \\
\hline P-value Wald Test & $0.000 * * *$ & $0.000 * * *$ & $0.000^{* * * *}$ & $0.000^{* * *}$ & $0.000 * * *$ & $0.000 * * *$ & $0.000 * * *$ \\
\hline
\end{tabular}

Note: Standard errors in ( ), z-statistics in [], *** indicates statistical significance at $1 \%$ level, $* *$ indicates statistical significance at 5\% level and * indicates statistical significance at $10 \%$ level. Coefficients, standard errors and z-statistics for the year dummies are not reported

Similarly to what we have done for the linear growth-model, we also present the results of our estimates for the non-linear growth model for all countries for both pre-crisis and crisis and post-crisis periods, respectively. The corresponding results are presented in Table 8 and Table 9. The results do not change dramatically in comparison with the same results of the linear growth model. Two main conclusions deserve our attention. Firstly, the existence of a concave quadratic relationship between finance and economic growth in the EU countries is also rejected both in the pre-crisis period and in the crisis and post-crisis periods. Secondly, the convex relationship between domestic credit and economic growth also occurs in the pre-crisis period, albeit the turning point has decreased slightly to a threshold of about $215 \%$ of the gross domestic product. 
The finance-growth nexus in the age of financialisation:

An empirical reassessment for the European Union countries

Table 8 - Estimates of the non-linear growth model for the pre-crisis period (1990-2008)

\begin{tabular}{|c|c|c|c|c|c|c|c|}
\hline Variable & $\begin{array}{l}\text { Money } \\
\text { Supply }\end{array}$ & $\begin{array}{c}\text { Domestic } \\
\text { Credit }\end{array}$ & $\begin{array}{c}\text { Financial } \\
\text { Value Added }\end{array}$ & $\begin{array}{c}\text { Short-term } \\
\text { Interest Rate }\end{array}$ & $\begin{array}{c}\text { Long-term } \\
\text { Interest Rate }\end{array}$ & $\begin{array}{c}\text { Stock Market } \\
\text { Volume } \\
\text { Traded } \\
\end{array}$ & $\begin{array}{l}\text { Stock Market } \\
\text { Capitalization }\end{array}$ \\
\hline \multirow{3}{*}{ Growth $_{t-1}$} & $0.471 * * *$ & $0.373 * * *$ & $0.334 * * *$ & $0.326^{* * * *}$ & $0.311 * * *$ & $0.351 * * *$ & $0.455^{* * *}$ \\
\hline & $(0.047)$ & $(0.080)$ & $(0.050)$ & $(0.046)$ & $(0.054)$ & $(0.048)$ & $(0.053)$ \\
\hline & [10.07] & [4.69] & [6.66] & [7.02] & {$[5.76]$} & {$[7.33]$} & {$[8.58]$} \\
\hline \multirow{3}{*}{ Inflation $_{t}$} & $-0.007 * * *$ & $-0.031 * * *$ & $-0.110^{* * *}$ & $-0.109 * * *$ & $-0.250 * * *$ & $-0.085^{* * *}$ & $-0.008 * * *$ \\
\hline & $(0.002)$ & $(0.010)$ & $(0.013)$ & (0.019) & $(0.053)$ & $(0.012)$ & $(0.002)$ \\
\hline & {$[-3.56]$} & {$[-3.31]$} & [-8.49] & {$[-5.87]$} & [-4.69] & {$[-7.24]$} & {$[-4.07]$} \\
\hline \multirow{4}{*}{$\begin{array}{l}\text { Government } \\
\text { Consumption }_{t}\end{array}$} & -0.129 & $-0.555 * * *$ & $-0.411 * * *$ & $-0.307 * * *$ & $-0.465 * * *$ & $-0.218^{* * *}$ & $-0.142^{*}$ \\
\hline & $(0.088)$ & $(0.192)$ & $(0.098)$ & $(0.084)$ & $(0.109)$ & $(0.085)$ & $(0.080)$ \\
\hline & {$[-1.47]$} & {$[-2.89]$} & [-4.19] & {$[-3.66]$} & {$[-4.27]$} & {$[-2.56]$} & {$[-1.77]$} \\
\hline & 0.009 & 0.012 & $0.021 * *$ & $0.030 * *$ & $0.019 * * *$ & $0.019 * *$ & $0.016 * *$ \\
\hline \multirow[t]{3}{*}{ Trade Openness $_{t}$} & $(0.008)$ & (0.019) & $(0.009)$ & $(0.009)$ & $(0.007)$ & $(0.008)$ & $(0.008)$ \\
\hline & [1.19] & {$[0.63]$} & [2.18] & [3.21] & [2.67] & {$[2.35]$} & {$[2.01]$} \\
\hline & 0.002 & 0.024 & 0.015 & -0.005 & -0.008 & 0.002 & 0.002 \\
\hline \multirow[t]{3}{*}{ Education $_{t}$} & $(0.014)$ & $(0.031)$ & $(0.016)$ & $(0.014)$ & $(0.013)$ & $(0.014)$ & $(0.014)$ \\
\hline & {$[0.12]$} & {$[0.76]$} & {$[0.94]$} & {$[-0.35]$} & {$[-0.62]$} & {$[0.15]$} & {$[0.08]$} \\
\hline & -0.013 & $-0.086 * * *$ & -0.043 & $-0.097 * *$ & -0.038 & $0.019 *$ & $0.029 * *$ \\
\hline \multirow[t]{3}{*}{ Finance $_{t}$} & $(0.015)$ & $(0.033)$ & $(0.245)$ & $(0.044)$ & $(0.055)$ & $(0.011)$ & $(0.012)$ \\
\hline & {$[-0.91]$} & {$[-2.59]$} & {$[-0.18]$} & {$[-2.23]$} & {$[-0.69]$} & [1.83] & [2.34] \\
\hline & 0.000 & $0.020 * *$ & -0.346 & -0.293 & -0.486 & -0.006 & $-0.010^{*}$ \\
\hline \multirow{2}{*}{ Finance $_{t}^{2}$} & $(0.004)$ & $(0.009)$ & $(0.668)$ & $(0.347)$ & $(0.713)$ & $(0.005)$ & $(0.005)$ \\
\hline & {$[0.08]$} & {$[2.16]$} & {$[-0.52]$} & {$[-0.85]$} & {$[-0.68]$} & {$[-1.34]$} & {$[-1.94]$} \\
\hline Finance* & n.a. & 215 & n.a. & n.a. & n.a. & n.a. & n.a. \\
\hline Observations & 419 & 168 & 350 & 391 & 344 & 410 & 413 \\
\hline Groups & 28 & 26 & 28 & 28 & 28 & 28 & 28 \\
\hline Time Effects & Yes & Yes & Yes & Yes & Yes & Yes & Yes \\
\hline P-value Wald Test & $0.000 * * *$ & $0.000 * * *$ & 0.000 *** & $0.000 * * *$ & $0.000 * * *$ & $0.000 * * *$ & $0.000 * * *$ \\
\hline
\end{tabular}

Note: Standard errors in ( ), z-statistics in [], *** indicates statistical significance at $1 \%$ level, ** indicates statistical significance at 5\% level and * indicates statistical significance at $10 \%$ level. Coefficients, standard errors and z-statistics for the year dummies are not reported

Table 9 - Estimates of the non-linear growth model for the crisis and post-crisis periods (2009-2016)

\begin{tabular}{|c|c|c|c|c|c|c|c|}
\hline Variable & $\begin{array}{l}\text { Money } \\
\text { Supply }\end{array}$ & $\begin{array}{c}\text { Domestic } \\
\text { Credit }\end{array}$ & $\begin{array}{c}\text { Financial } \\
\text { Value Added }\end{array}$ & $\begin{array}{c}\text { Short-term } \\
\text { Interest Rate }\end{array}$ & $\begin{array}{c}\text { Long-term } \\
\text { Interest Rate }\end{array}$ & $\begin{array}{c}\text { Stock Market } \\
\text { Volume } \\
\text { Traded }\end{array}$ & $\begin{array}{l}\text { Stock Market } \\
\text { Capitalization }\end{array}$ \\
\hline \multirow{4}{*}{ Growth $_{t-1}$} & $0.330 * * *$ & 0.084 & $0.128^{* *}$ & 0.091 & -0.042 & $0.384 * * *$ & $0.386 * * *$ \\
\hline & $(0.054)$ & $(0.079)$ & $(0.061)$ & $(0.061)$ & $(0.057)$ & $(0.066)$ & $(0.046)$ \\
\hline & [6.14] & {$[1.06]$} & {$[2.10]$} & [1.49] & {$[-0.73]$} & [5.81] & [8.46] \\
\hline & -0.162 & 0.021 & -0.208 & -0.200 & $-0.327 *$ & -0.299 & $-0.388 * *$ \\
\hline \multirow[t]{2}{*}{ Inflation $_{t}$} & $(0.179)$ & $(0.190)$ & $(0.187)$ & $(0.156)$ & $(0.178)$ & $(0.215)$ & $(0.189)$ \\
\hline & {$[-0.91]$} & {$[0.11]$} & {$[-1.12]$} & {$[-1.28]$} & {$[-1.84]$} & {$[-1.39]$} & {$[-2.05]$} \\
\hline \multirow{4}{*}{$\begin{array}{c}\text { Government } \\
\text { Consumption }_{t}\end{array}$} & $-1.356 * * *$ & $-0.840 * * *$ & $-1.263^{* * *}$ & $-1.119 * * *$ & $-1.244 * * *$ & $-1.848 * * *$ & $-1.112 * * *$ \\
\hline & $(0.317)$ & $(0.265)$ & $(0.296)$ & $(0.238)$ & $(0.227)$ & $(0.316)$ & $(0.325)$ \\
\hline & {$[-4.28]$} & {$[-3.17]$} & {$[-4.27]$} & {$[-4.71]$} & {$[-5.47]$} & {$[-5.84]$} & {$[-3.42]$} \\
\hline & $0.093 * * *$ & 0.032 & $0.048^{* * *}$ & $0.036^{* *}$ & $0.028 *$ & 0.067 **** & $0.068 * * *$ \\
\hline \multirow[t]{3}{*}{ Trade Openness $_{t}$} & $(0.032)$ & $(0.020)$ & $(0.020)$ & $(0.016)$ & $(0.017)$ & $(0.025)$ & $(0.023)$ \\
\hline & [2.91] & {$[1.61]$} & [2.38] & [2.27] & [1.68] & {$[2.62]$} & [3.00] \\
\hline & 0.026 & 0.010 & 0.044 & 0.025 & 0.031 & -0.057 & -0.064 \\
\hline \multirow{3}{*}{ Education $_{t}$} & $(0.028)$ & $(0.029)$ & $(0.028)$ & $(0.024)$ & $(0.026)$ & $(0.053)$ & $(0.065)$ \\
\hline & {$[0.91]$} & {$[0.36]$} & {$[1.60]$} & [1.03] & [1.19] & {$[-1.07]$} & {$[-0.99]$} \\
\hline & -0.065 & -0.046 & -0.940 & $-0.662 * * *$ & $-0.668 * * *$ & -0.066 & -0.061 \\
\hline \multirow[t]{3}{*}{ Finance $_{t}$} & $(0.089)$ & $(0.056)$ & $(0.898)$ & $(0.124)$ & $(0.121)$ & $(0.059)$ & $(0.042)$ \\
\hline & {$[-0.73]$} & {$[-0.82]$} & {$[-1.05]$} & {$[-5.34]$} & {$[-5.52]$} & {$[-1.11]$} & {$[-1.45]$} \\
\hline & 0.018 & 0.002 & 1.061 & 2.388 & 1.081 & 0.037 & $0.039 * *$ \\
\hline \multirow[t]{2}{*}{ Finance $_{t}{ }_{t}$} & $(0.026)$ & $(0.016)$ & $(2.548)$ & $(3.420)$ & $(0.659)$ & $(0.024)$ & $(0.018)$ \\
\hline & {$[0.69]$} & {$[0.15]$} & {$[0.42]$} & {$[0.70]$} & {$[1.64]$} & {$[1.57]$} & {$[2.21]$} \\
\hline $\begin{array}{c}\text { Finance* } \\
\text { Observations }\end{array}$ & $\begin{array}{l}\text { n.a. } \\
134\end{array}$ & $\begin{array}{l}\text { n.a. } \\
152\end{array}$ & $\begin{array}{l}\text { n.a. } \\
153\end{array}$ & $\begin{array}{l}\text { n.a. } \\
150\end{array}$ & $\begin{array}{l}\text { n.a. } \\
143\end{array}$ & $\begin{array}{l}\text { n.a. } \\
108\end{array}$ & $\begin{array}{l}\text { n.a. } \\
106\end{array}$ \\
\hline Groups & 28 & 28 & $\begin{array}{c}153 \\
28\end{array}$ & $\begin{array}{l}150 \\
28\end{array}$ & $\begin{array}{l}143 \\
26\end{array}$ & $\begin{array}{l}108 \\
28\end{array}$ & $\begin{array}{l}100 \\
28\end{array}$ \\
\hline Time Effects & Yes & Yes & Yes & Yes & Yes & Yes & Yes \\
\hline P-value Wald Test & $0.000 * * *$ & $0.000 * * *$ & $0.000^{* * * *}$ & $0.000 * * *$ & $0.000^{* * * *}$ & $0.000^{* * * *} *$ & $0.000 * * *$ \\
\hline
\end{tabular}

Note: Standard errors in ( ), Z-statistics in [], *** indicates statistical significance at $1 \%$ level, ** indicates statistical significance at $5 \%$ level and $*$ indicates statistical significance at $10 \%$ level. Coefficients, standard errors and z-statistics for the year dummies are not reported 


\subsection{ECONOMIC EFFECTS}

Finally, we present the economic significance (Deirdre McCloskey and Stephen Ziliak, 1996; and Stephen Ziliak and Deirdre McCloskey 2004) of the proxies of finance that proved to be statistically significant on the linear growth models ${ }^{5}$. This allows to assess properly the contribution of each proxy of finance to the economic growth of the EU countries since 1990. Results are presented in Table 10. Considering the full period as a whole, we conclude that the growth of finance has in fact contributed to a fall in economic growth in the EU countries. Effectively, the increase in domestic credit and of the financial value added contributed to a decline in economic growth by about 1.1 and 1.4 percent, respectively. In the pre-crisis period, this detrimental effect of finance on economic growth of the EU countries was even more pronounced. Economic growth would have been higher by around 1.8 per cent if there had not been a jump in the growth of domestic credit. In the crisis and post-crisis periods, there was a reversal in the growth of finance, which was beneficial for the economic growth of the EU countries. Effectively, the contraction of domestic credit and of financial value added in the aftermath of the Great Recession delineated an acceleration of economic growth in the EU countries by about 0.6 and 8.4 percent, respectively. The sustained fall in the level of real interest rates since 1990 contributed decisively to a higher level of economic growth in the EU countries, both in the pre-crisis period and in the crisis and post-crisis periods.

To sum up, our results do not support the finance-growth nexus hypothesis by confirming that finance has instigated a drop in the economic growth of EU countries, particularly in the period leading up to the Great Recession where the growth of finance was more evident. As we observe since the Great Recession, a reversal in the importance of finance seems to be necessary in the coming years, i.e. a de-financialisation process, in order to sustain a higher level of economic growth in the EU countries. Otherwise, the hypothesis of a new 'secular stagnation' in the current age of financialisation will gain momentum.

\footnotetext{
5 This analysis only focues on the estimates of the linear growth models due to the statistical insignificance of the non-linear relationship between finance and economic growth.

DINÂMIA'CET - IUL, Centro de Estudos sobre a Mudança Socioeconómica e o Território do Instituto Universitário de Lisboa (ISCTE-IUL)

Sala 2W4 - D | ISCTE-IUL - Av. das Forças Armadas 1649-026 Lisboa, PORTUGAL 
Table 10 - Economic significance of our statistically significant estimates of the linear growth model

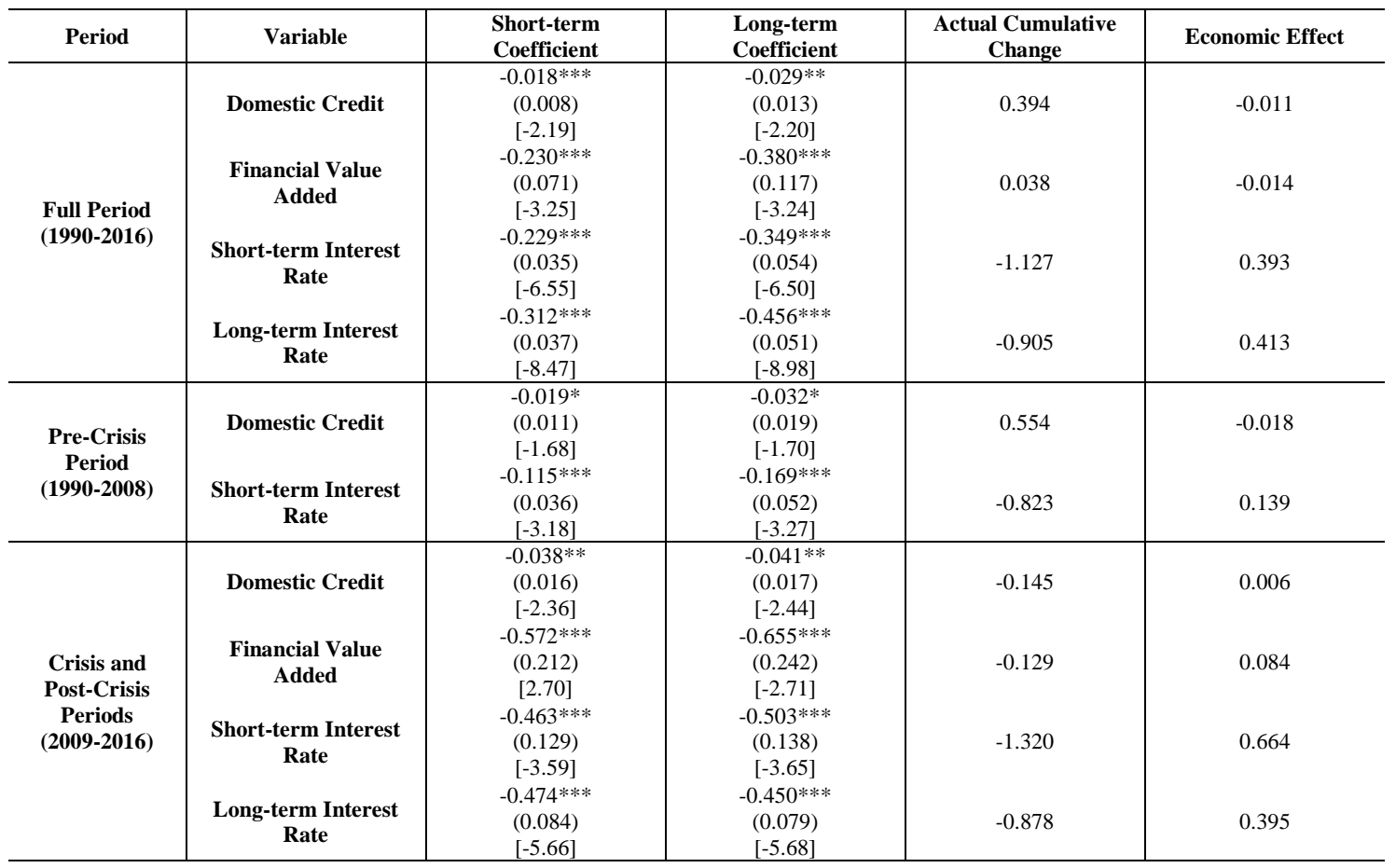

Note: Standard errors in ( ), Z-statistics in [], *** indicates statistical significance at $1 \%$ level, ** indicates statistical significance at $5 \%$ level and * indicates statistical significance at $10 \%$ level. The longterm coefficient is obtained through the division between the short-term coefficient (estimated coefficient) and one minus the coefficient of the autoregressive estimation (estimated lagged growth rate of the real per capita gross domestic product coefficient) by performing the 'nlcom' command in the Stata software. The actual cumulative change corresponds to the growth rate of the correspondent variable. The economic effect is the multiplication of the long-term coefficient by the actual cumulative change

\section{CONCLUSION}

This paper aimed to assess an empirical re-examination of the finance-growth nexus by conducting a panel data econometric analysis for all 28 European Union countries over 27 years from 1990 to 2016.

This is particularly challenging due to the emergence of several empirical studies that have not supported the hypothesis on the finance-growth nexus (Rioja and Valev, 2004a and 2004b; Aghion, Howitt and Mayer-Foulkes, 2005; Kose et al., 2006; Prasad, Rajan and Subramanian, 2007; Rousseau and Wachtel, 2011; Cecchetti and Kharroubi, 2012; Barajas, Chami and Yousefi, 2013; Dabla-Norris and Srivisal, 2013; Beck, Degryse and Kneer, 2014; Breitenlechner, Gächter and Sindermann, 2015; Ehigiamusoe and Lean, 2017; Alexiou, Vogiazas and Nellis, 2018), mainly in the period since the mid-1980s. During that time, the financial system has been subjected to strong liberalisation and deregulation by preventing its beneficial effects on the real economy. This phenomenon, typically called financialisation, points to a negative view of finance and contradicts the well-established hypothesis on the finance-growth nexus.

\footnotetext{
DINÂMIA'CET - IUL, Centro de Estudos sobre a Mudança Socioeconómica e o Território do Instituto Universitário de Lisboa (ISCTE-IUL)

Sala 2W4 - D | ISCTE-IUL - Av. das Forças Armadas 1649-026 Lisboa, PORTUGAL

Tel. (+351) 210464031 / 210464197 | E-mail: dinamia@iscte-iul.pt | www.dinamiacet.iscte-iul.pt
} 
Hence, we estimated both a linear growth model and a non-linear growth model using the LSDVBC estimator taking into account that we have a dynamic panel data model due to the inclusion of the lagged growth rate among the control variables, an unbalanced panel due to the presence of some missing values in our sample, a macro panel due to the relatively small crosssectional dimension $N$ of our sample and the possible existence of endogeneity due to the aforementioned potential reverse causation between finance and growth. We used different proxies of finance (money supply, domestic credit, financial value added, short-term interest rate, long-term interest rate, stock market volume traded and stock market capitalisation) in order to offer a complete picture of the role of finance on economic growth and to capture different dimensions of finance, namely the financial depth, the overall size of financial intermediation activity and their corresponding efficiency (Beck, Degryse and Kneer, 2014; Breitenlechner, Gächter and Sindermann, 2015). In addition, our growth models also incorporate five control variables (the lagged growth rate of the real per capita gross domestic product, the inflation rate, the general government consumption, the degree of trade openness and the education level of the population) in line with other empirical studies around this matter (Rioja and Valev, 2004; Hassan, Sanchez and Yu, 2011; Rousseau and Wachtel, 2011; Cecchetti and Kharroubi, 2012; Beck, Degryse and Kneer, 2014; Breitenlechner, Gächter and Sindermann, 2015; Ehigiamusoe and Lean, 2017).

The paper corroborates the results of these empirical studies, namely by confirming that the lagged growth rate of the real per capita gross domestic product and trade openness are positive determinants of economic growth in the EU countries, whilst the inflation rate and general government consumption are negative determinants. The paper finds that finance impairs economic growth in the EU countries, both in the pre-crisis and in the crisis and postcrisis periods, thus not supporting the finance-growth nexus hypothesis. It is also concluded that the spectacular growth of domestic credit and of financial value added favoured a drop in economic growth in EU countries since 1990 and particularly in the years leading up to the Great Recession. The paper also does not confirm the existence of a non-linear relationship between finance and economic growth in the EU countries, which seems to rule out the possibility of finance having an inverted U-shaped effect on economic growth in the EU countries.

Our results suggest that it is necessary to reduce the importance of finance in the coming years, i.e. to engage in a de-financialisation process, in order to sustain a higher level of economic growth in the EU countries. Otherwise, the hypothesis of a new 'secular stagnation' in the current age of financialisation may become real. 


\section{REFERENCES}

AGHION, Philippe, Peter Howitt, and David Mayer-Foulkes. 2005. "The Effect of Financial Development on Convergence: Theory and Evidence". Quarterly Journal of Economics, 120(1): 173-222.

ALEXIOU, Constantinos, and Joseph Nellis. 2013. "Challenging the Raison d'etre of Internal Devaluation in the Context of the Greek Economy". Panoeconomicus, 60(6): 813-836.

ALEXIOU, Constantinos, Sofoklis Vogiazas, and Joseph Nellis. 2018. "Reassessing the relationship between the financial sector and economic growth: Dynamic panel evidence", International Journal of Finance \& Economics, 23(2): 155-173.

ANDERSON, T. W., and Cheng Hsiao. 1982. "Formulation and estimation of dynamic models using panel data". Journal of Econometrics, 18 (1): 570-606.

ANG, James B. 2008. "A Survey of Recent Developments in the Literature of Finance and Growth". Journal of Economic Surveys, 22(3): 536-576.

ARESTIS, Philip, Georgios Chortareas, and Georgios Magkonis. 2015. "The Financial Development and Growth Nexus: A Meta-Analysis". Journal of Economic Surveys, 29(3): 549565.

ARRELANO, Manuel, and Stephen Bond. 1991. "Some Tests of Specification for Panel Data: Monte Carlo Evidence and an Application to Employment Equations". Review of Economic Studies, 58 (2): 277-297.

ARRELANO, Manuel, and Olympia Bover. 1995. "Another look at the instrumental variable estimation of error-components models". Journal of Econometrics, 68(1): 29-51.

BALTAGI, Badi. 2005. Econometric Analysis of Panel Data. $3^{\text {rd }}$ Edition. New York: John Wiley \& Sons, Ltd.

BARAJAS, Adolfo, Ralph Chami, and Seyed Reza Yousefi. 2013. "The Finance and Growth Nexus Re-Examined: Do All Countries Benefit Equally?”. IMF Working Paper 13/130. 
BARRADAS, Ricardo. 2016. "Evolution of the Financial Sector - Three Different Stages: Repression, Development and Financialisation”. In Advances in Applied Business Research: the L.A.B.S. Initiative, ed Gomes, Orlando and Hélder Fanha Martins. New York: Nova Science Publishers.

BARRO, Robert J. 1991. "Economic Growth in a Cross Section of Countries". The Quarterly Journal of Economics, 106(2): 407:443.

BARRO, Robert J. 2003. "Determinants of Economic Growth in a Panel of Countries". Annals of Economics and Finance, 4(2): 231-274.

BECK, Thorsten, Hans Degryse, and Christiane Kneer. 2014. "Is more finance better? Disentangling intermediation and size effects of financial systems". Journal of Financial Stability, 10(1): 50-64.

BEHR, Andreas. 2003. "A comparison of dynamic panel data estimators: Monte Carlo evidence and an application to the investment function. Economic Research Centre of the Deutsche Bundesbank Discussion Paper 05/03.

BLUNDELL, Richard, and Stephen Bond. 1998. "Initial conditions and moment restrictions in dynamic panel-data models". Journal of Econometrics, 87(1): 115-143.

BREITENLECHNER, Max, Martin Gächter, and Friedrich Sindermann. 2015. "The financegrowth nexus in crisis". Economics Letters, 132(1): 31-33

BROOKS, Chris. 2009. Introductory Econometrics for Finance. $2^{\text {nd }}$ Edition. New York: Cambridge University Press.

BRUNO, Giovanni S. F. 2005a. "Approximating the bias of the LSDV estimator for dynamic unbalanced panel data models". Economic Letters, 87(3): 361-366.

BRUNO, Giovanni S. F. 2005b. "Estimation and inference in dynamic unbalanced panel-data models with a small number of individuals". The Stata Journal, 5(4): 473-500.

BUN, Maurice J. G., and Jan F. Kiviet. 2003. "On the diminishing returns of higher orders terms in asymptotic expansions of bias". Economic Letters, 79(2): 145-152. 
CAMERON, A. Colin, and Pravin K. Trivedi. 2009. Microeconometrics Using Stata. Texas: Stata Press.

CECCHETTI, Stephen G., and Enisse Kharroubi. 2012. "Reassessing the impact of finance on growth”. BIS Working Paper 381.

DABLA-NORRIS, Era, and Narapong Srivisal. 2013. "Revisiting the Link Between Finance and Macroeconomic Volatility”. IMF Working Paper 13/29.

DURUSU-CIFTCI., Dilek, M. Serdar Ispir, and Hakan Yetkiner. 2017. "Financial development and economic growth: Some theory and more evidence". Journal of Policy Modeling, 39(2): 290-306.

SEBASTIAN, Edwards. 1996. "Why are Latin American's savings rate so low? An international comparative analysis". Journal of Development Economics. 51(1): 5-44.

EHIGIAMUSOE, Kizito Uyi, and Hooi Hooi Lean. 2018. "Finance-Growth Nexus: New Insights from the West African Region”. Emerging Markets Finance and Trade, 54(11): 25962613.

EPSTEIN, Gerald A. 2005. Financialisation and the World Economy. Cheltenham: Edward Elgar Publishing Limited.

FISCHER, Stanley. 1993. "The Role of Macroeconomic Factors in Growth”. NBER Working Paper 4565 .

FRIEDMAN, Milton. 1953. Essays in Positive Economics. Chicago: Chicago University Press.

GROCHOWSKA, Anna, Ioana Diaconescu, Aliénor Margerit, and Rada Tomova. 2014. "Financing the recovery: the State of Europe's financial sector". ECFIN Economic Brief 33.

HAAN, Jakob de, Sander Oosterloo, and Dirk Schoenmaker. 2015. Financial Markets and Institutions: A European Perspective. $3^{\text {rd }}$ Edition. Cambridge: Cambridge University Press.

HASSAN, M. Kabir, Benito Sanchez, and Jung-Suk Yu. 2011. "Financial development and economic growth: New evidence from panel data". The Quarterly Review of Economics and Finance, 51(1): 88-104.

\footnotetext{
DINÂMIA'CET - IUL, Centro de Estudos sobre a Mudança Socioeconómica e o Território do Instituto Universitário de Lisboa (ISCTE-IUL)

Sala 2W4 - D | ISCTE-IUL - Av. das Forças Armadas 1649-026 Lisboa, PORTUGAL 
JEDIDIA, Khoutem Ben, Thouraya Boujelbène, and Kamel Helali. 2014. "Financial development and economic growth: New evidence from Tunisia”. Journal of Policy Modeling, 36(5): 883-898.

JUDSON, Ruth A., and Ann L. Owen. 1999. "Estimating dynamic panel data models: a guide for macroeconomists". Economic Letters, 65(1): 9-15.

KING, Robert G., and Ross Levine. 1993. "Finance and Growth: Schumpeter Might be Right". Quarterly Journal of Economics, 108(3): 717-737.

KIVIET, Jan F. 1995. "On bias, inconsistency, and efficiency of various estimators in dynamic panel data models". Journal of Econometrics, 68(1): 53-78.

KOSE, M. Ayhan, Eswar Prasad, Kenneth Rogoff, and Shang-Jin Wei. 2006. "Financial Globalization: A Reappraisal". IMF Staff Papers, 56(1): 8-62.

KUTNER, Michael, Christopher Nachtsheim, John Neter, and William Li. 2004. Applied Linear Statistical Models. $5^{\text {th }}$ Edition. New York: Irwin/McGraw-Hill.

LAPAVITSAS, Costas. 2011. "Theorizing financialization". Work, Employment and Society, 25(4): 611-626.

LEVINE, Ross. 2005. "Finance and Growth: Theory and Evidence". In Handbook of Economic Growth, ed Aghion, Peter, and Steven Durlauf, 865-934. Amsterdam: Elsevier.

LUCARELLI, Bill. 2012. "Financialization and Global Imbalances: Prelude to Crisis". Review of Radical Political Economics, 44(4): 429-447.

MCCLOSKEY, Deirdre N. and Stephen T. Ziliak. 1996. "The Standard Error of Regressions". Journal of Economic Literature, 34(1): 97-114.

MENKHOFF, Lukas, and Norbert Tolksdorf. 2001. Financial Market Drift: Decoupling of the Financial Sector from the Real Economy. Berlin: Springer.

MINSKY, Hyman P. 1991. "The Financial Instability Hypothesis: A Clarification”. In The Risk of Economic Crisis, ed Feldstein, Martin, 158-166. Chicago, IL, and London: University of Chicago Press. 
NICKELL, Stephen. 1981. "Biases in Dynamic Models with Fixed Effects". Econometrica, 49(6): 1417-1426.

ORHANGAZI, Özgür. 2008. Financialization and the US Economy. Cheltenham: Edward Elgar Publishing Limited.

PALLEY, Thomas I. 2007. "Financialisation: What it is and Why it Matters". Political Economy Research Institute Working Paper 153.

PRASAD, Eswar, S., Raghuram G. Rajan, and Arvind Subramanian. 2007. "Foreign Capital and Economic Growth". NBER Working Paper 13619.

RIOJA, Felix, and Neven Valev. 2004a. "Finance and the Sources of Growth at Various Stages of Economic Development". Economic Inquiry Journal, 42(1): 127-140.

RIOJA, Felix, and Neven Valev. 2004b. "Does one size fit all? A reexamination of the finance and growth relationship". Journal of Development Economics. 74(1): 429-447.

ROUSSEAU, Peter L., and Paul Wachtel. 2011. "What is happening to the impact of financial deepening on economic growth?". Economic Inquiry, 49(1): 276-288.

SAWYER, Malcolm. 2014. "Financial development, financialisation and economic growth". FESSUD Working Paper 21.

SAWYER, Malcolm. 2015. "Financialisation, financial structures, economic performance and employment". FESSUD Working Paper 93.

SCHNABL, Gunther. 2009. "Exchange Rate Volatility and Growth in Emerging Europe and East Asia". Open Economies Review, 20(4): 565-587.

SHAW, Edward S. 1973. Financial Deepening in Economic Development. New York: Oxford University Press.

STOCKHAMMER, Engelbert. 2010. "Financialization and the Global Economy". Political Economy Research Institute Working Paper 240.

VALICKOVA, Petra, Thomas Havranek, and Roman Horvath. 2014. "Financial Development and Economic Growth: A Meta-Analysis”. Journal of Economic Surveys, 29(3): 506-526.

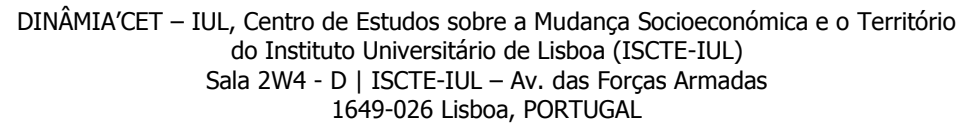


VAN DER ZWAN, Natascha. 2014. "Making sense of financialization". Socio-Economic Review, 12(1):99-129.

WINTERS, L. Alan. 2004. "Trade Liberalization and Economic Performance: An Overview". The Economic Journal, 114(1): 4-21.

WOOLDRIDGE, Jeffrey M. 2003. Introductory Econometrics: A Modern Approach. $2^{\text {nd }}$ Edition. Ohio: Thomson South-Western.

ZILIAK, Stephen T., and Deirdre N. McCloskey. 2004. "Size matters: the standard error of regressions in the American Economic Review". The Journal of Socio-Economics, 33(5): 52754.

\section{APPENDIX}

Figure A1 - Unweighted mean of GDP per capita growth (annual \%)

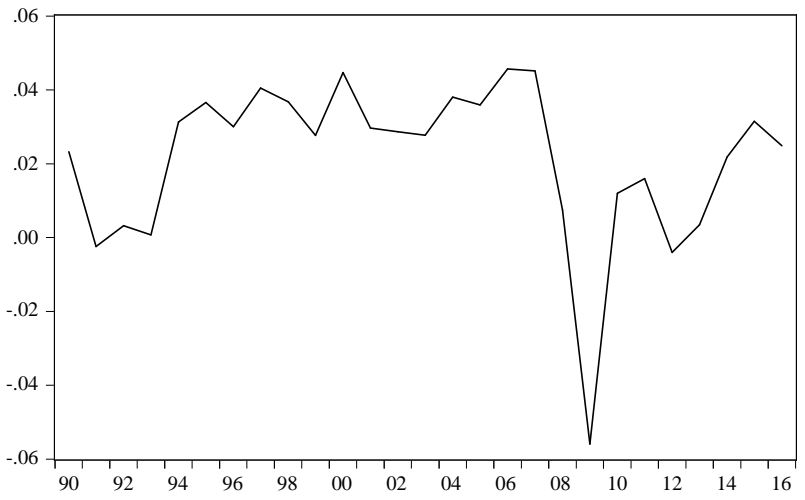

Figure A2 - Unweighted mean of inflation (annual \%)

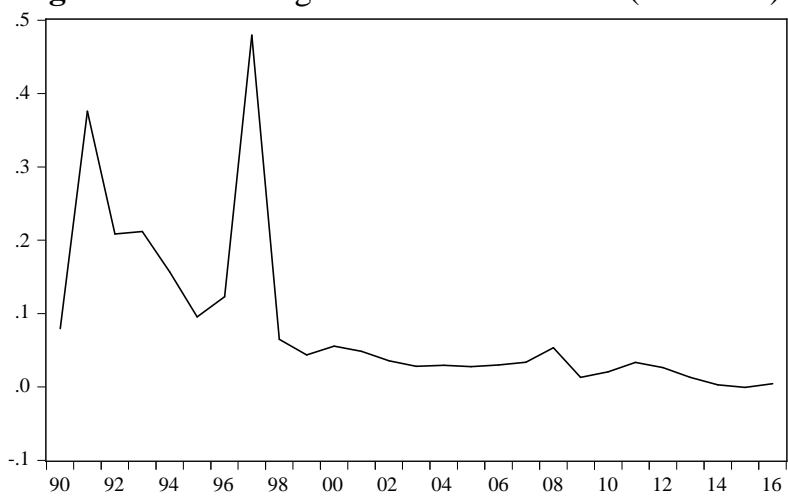

DINÂMIA'CET - IUL, Centro de Estudos sobre a Mudança Socioeconómica e o Território do Instituto Universitário de Lisboa (ISCTE-IUL)

Sala 2W4 - D | ISCTE-IUL - Av. das Forças Armadas 1649-026 Lisboa, PORTUGAL 
The finance-growth nexus in the age of financialisation:

An empirical reassessment for the European Union countries

Figure A3 - Unweighted mean of general government final consumption expenditure (\% of GDP)

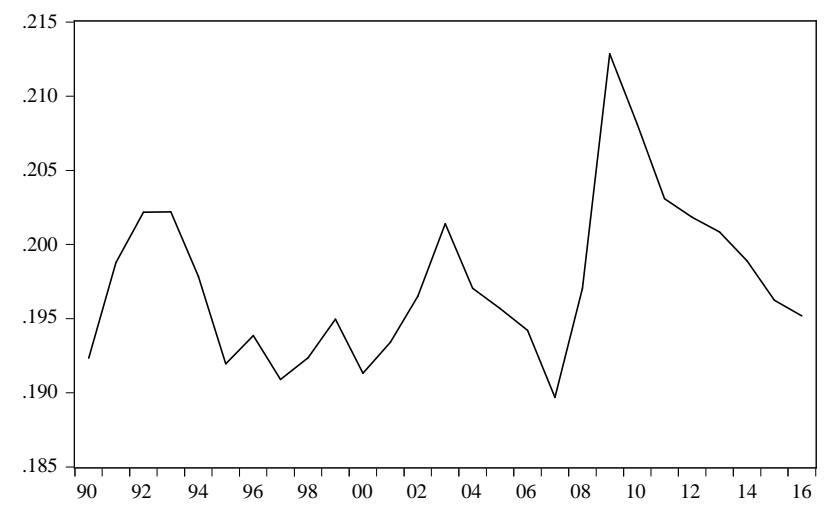

Figure A4 - Unweighted mean of exports and imports of goods and services (\% of GDP)

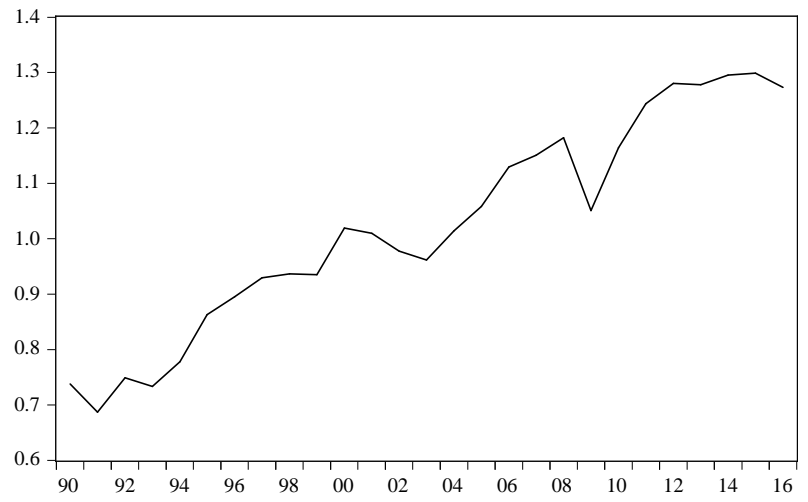

Figure A5 - Unweighted mean of secondary school enrolment (\% gross)

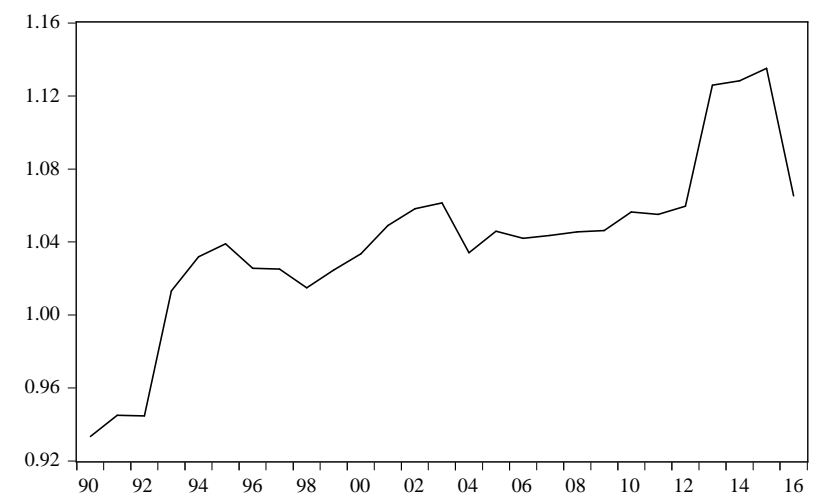

DINÂMIA'CET - IUL, Centro de Estudos sobre a Mudança Socioeconómica e o Território do Instituto Universitário de Lisboa (ISCTE-IUL)

Sala 2W4 - D | ISCTE-IUL - Av. das Forças Armadas

1649-026 Lisboa, PORTUGAL

Tel. (+351) 210464031 / 210464197 | E-mail: dinamia@iscte-iul.pt | www.dinamiacet.iscte-iul.pt 
The finance-growth nexus in the age of financialisation:

An empirical reassessment for the European Union countries

Figure A6 - Unweighted mean of liquid liabilities (\% of GDP)

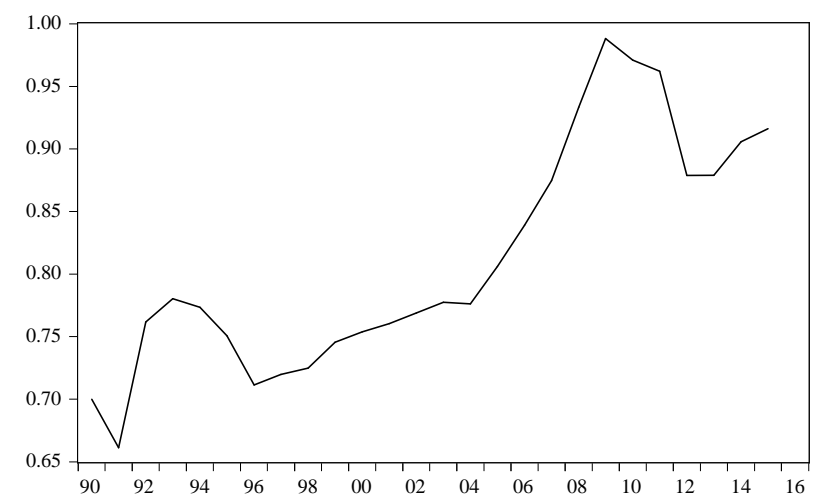

Figure A7 - Unweighted mean of domestic credit provided by financial sector (\% of GDP)

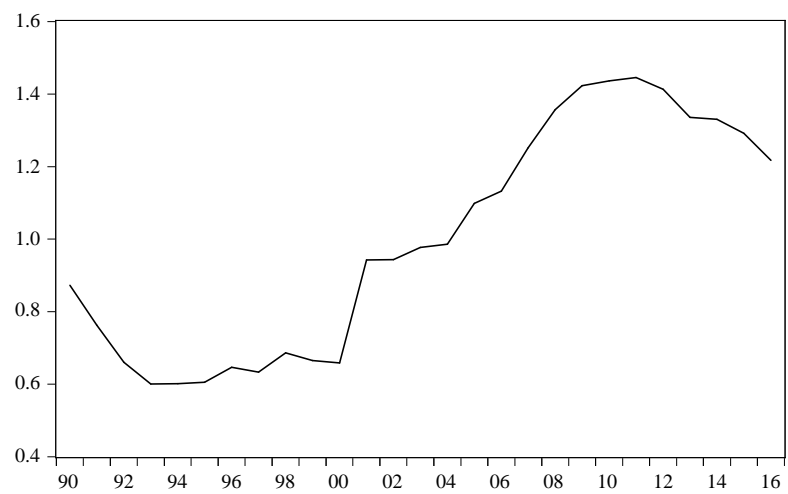

Figure A8 - Unweighted mean of gross value added of financial activities (\% of total)

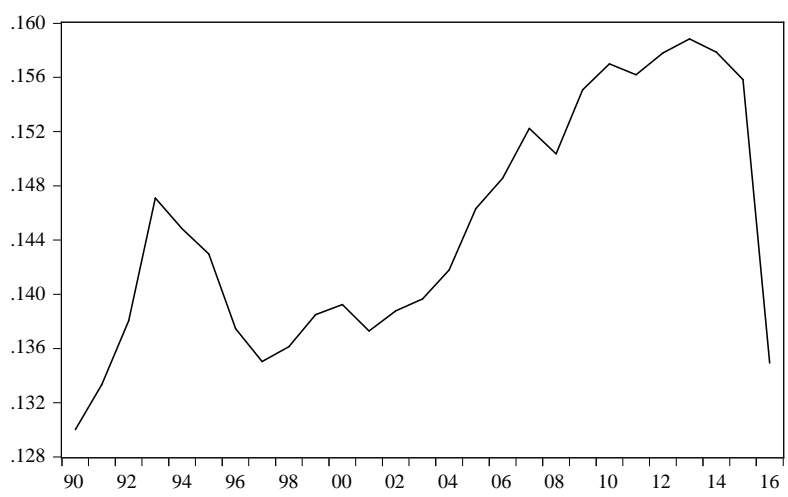

DINÂMIA'CET - IUL, Centro de Estudos sobre a Mudança Socioeconómica e o Território do Instituto Universitário de Lisboa (ISCTE-IUL)

Sala 2W4 - D | ISCTE-IUL - Av. das Forças Armadas 1649-026 Lisboa, PORTUGAL

Tel. (+351) 210464031 / 210464197 | E-mail: dinamia@iscte-iul.pt | www.dinamiacet.iscte-iul.pt 
The finance-growth nexus in the age of financialisation:

An empirical reassessment for the European Union countries

Figure A9 - Unweighted mean of real short-term interest rate, deflator GDP (\%)

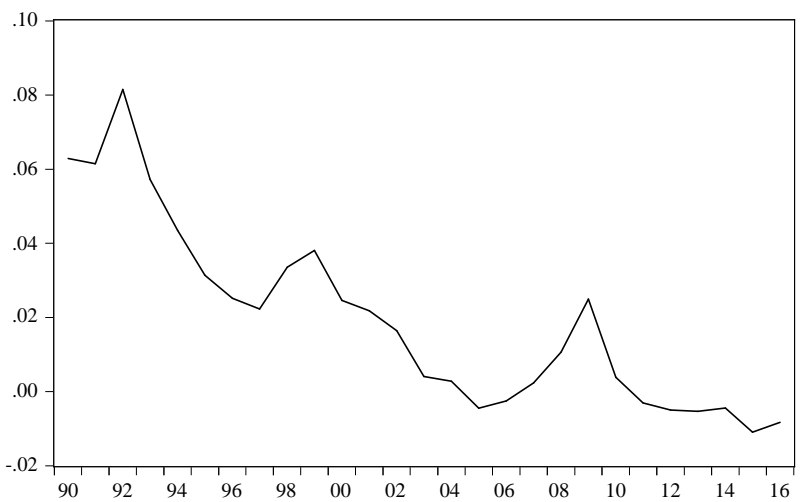

Figure A10 - Unweighted mean of real long-term interest rate, deflator GDP (\%)

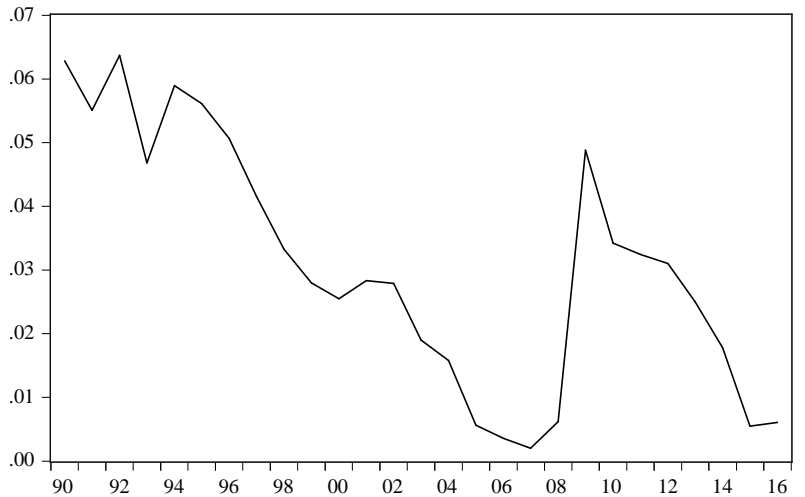

Figure A11 - Unweighted mean of the stock market total volume traded (\% of GDP)

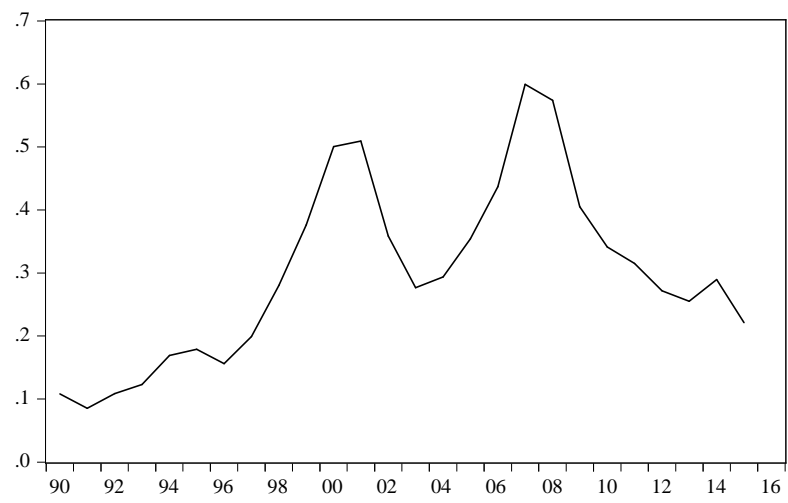

Figure A12 - Unweighted mean of stock market capitalisation (\% of GDP)

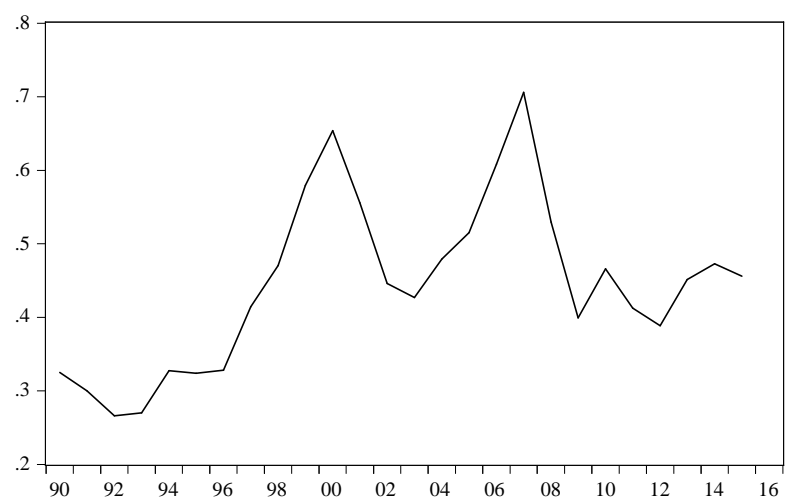

DINÂMIA'CET - IUL, Centro de Estudos sobre a Mudança Socioeconómica e o Território do Instituto Universitário de Lisboa (ISCTE-IUL)

Sala 2W4 - D | ISCTE-IUL - Av. das Forças Armadas

1649-026 Lisboa, PORTUGAL

Tel. (+351) 210464031 / 210464197 | E-mail: dinamia@iscte-iul.pt | www.dinamiacet.iscte-iul.pt 